\title{
STRUCTURAL AND ENVIRONMENTAL VARIABILITY FROM THE EDGE TO THE INTERIOR OF AN ATLANTIC FOREST REMNANT IN BRAZIL
}

\author{
Dias PB ${ }^{1, *}$, Gomes LP², Callegaro RM${ }^{3}$, Carvalho FA ${ }^{4} \&$ Dias $\mathrm{HM}^{5}$ \\ ${ }^{1}$ Universidade Federal Espírito Santo/UFES, Departamento de Ciências Florestais e da Madeira, Núcleo de Pesquisa \\ Científica e Tecnológica em Meio Ambiente, Silvicultura e Ecologia - NUPEMASE, Avenida Governador Lindemberg, \\ 316, 29550-000, Jerônimo Monteiro, ES, Brasil \\ ${ }^{2}$ Universidade Federal de Viçosa/UFV, Departamento de Biologia Vegetal, Laboratório de Ecologia e Evolução de Plantas - \\ LEEP, 36570-900, Viçosa, MG, Brasil \\ ${ }^{3}$ Universidade Federal do Pampa/UNIPAMPA, Campus São Gabriel, Rua Aluizio Barros Macedo, s/n, BR 290 - km 423, \\ 97307-020, São Gabriel, RS, Brasil \\ ${ }^{4}$ Universidade Federal de Juiz de Fora/UFJF, Departamento de Botânica, Campus Universitário, sn, Martelos, 36036-900, \\ Juiz de Fora, MG, Brasil \\ ${ }^{5}$ Universidade Federal Espirito Santo, Centro de Ciências Agrárias e Engenharias, Departamento de Ciências Florestais e \\ da Madeira, Jerônimo Monteiro, ES, Brasil
}

*patríciaborgesdias@yahoo.com.br

Submitted June 2020; accepted November 2020

\begin{abstract}
This study described the floristic-structural variations between edges consisting of one bordering the road and the other by the forest stands with the interior of the forest. The effects of the relationships between environmental aspects in the Atlantic Forest remnant in Brazil was also studied. The structure of the vegetation stratum differed between the edges with the interior and the relationship between the distribution of species with the environmental variables reflected the changes which occurred in the edges towards the interior. For vegetation sampling, 36 plots were established over an area of 0.9 ha and were distributed on both edges and inside the remnant. All individuals with diameter at breast height of $\geq 2.5 \mathrm{~cm}$ were measured and identified. The results revealed the differences in the structure and composition of species distribution pattern in the remnant were influenced by environmental variables such as humidity, resistance to penetration, cation exchange capacity and sodium and potassium contents. These results reinforced the need to create conservation strategies to minimise forest degradation and loss of biodiversity in these forest ecosystems.
\end{abstract}

Keywords: Edge effect, core area, matrix influence, fragment size, protected area

\section{INTRODUCTION}

The Atlantic Forest is one of the most biodiverse environments on the planet and listed as a priority biome in the Brazilian conservation policies (Rezende et al. 2018). The area not only has high species richness, high local and regional levels of endemism but also high susceptibility to degradation (Mittermeier et al. 2004). Based on the current situation of this biome, Laurance (2008) stated that few fragmented hotspots were vulnerable and may cause reduction of the Brazilian Atlantic Forest.

The fragmentation of ecosystems is the main factor for area and species loss (Magnago et al. 2014). Fragmentation is directly related to the changes in forest environment due to the influences of surrounding anthropised habitats and is known as edge effect (Murcia 1995, Meeussen et al. 2020). Changes in the microclimate of the fragment edge such as wind intensity, light levels, temperature and humidity (Harper et al. 2005) can influence the composition of tree species, vegetation structure, carbon stock, migration of animals and invasion of exotic species. Due to the anthropised external environment, the loss of genetic variability in native species is rampant (Zhang \& Zang 2011, Wekesa et al. 2019).

Therefore, studies on vegetation and its relationship with environmental variables are of paramount importance, as they provide supports 
in the conservation and management of forest remnants (Souza et al. 2017) especially for the protected areas of the original Atlantic Forest, which consisted of only $1 \%$ of the total area (Ribeiro et al. 2009).

The study aimed to analyse the floristicstructural variations between the edges with the interior of the forest and the implications of the relationships between environmental aspects with the plant community. The two main objectives of this work were to determine the structure of the vegetation layer differences between the edges and the interior of the forest remnant and to study the relationship between the distribution of the plant species and the changes of environmental variables from the edges to the interior of the forest remnant.

\section{MATERIALS AND METHODS}

\section{Study area}

The study was conducted in a remnant of tropical dense ombrophilous lowland forest in the Córrego Grande Biological Reserve which is located in the municipality of Conceição da Barra $\left(18^{\circ} 12^{\prime} \mathrm{S}\right.$ and $\left.39^{\circ} 45^{\prime} \mathrm{W}\right)$ in the extreme north in the state of Espírito Santo in Brazil. Córrego Grande Biological Reserve has a triangular physiognomic shape of approximately 1504 ha (Figure 1), containing stands of Eucalyptus spp., pastures of private properties and an $8-\mathrm{km}$ contiguous ground road named Picadão da Bahia, which constitutes the border between the states of Espírito Santo and Bahia (Rezende 2012). In the study, the following treatments areas were established; the road and the forest edges, mostly Eucalyptus stands and the interior of the remainder as control.

Before its conversion to a biological reserve (Brasil 1989), the area was a legal private property reserve (Rezende 2012). The reserve suffered a fire outbreak in 1987 which reached one third of its original vegetation cover and possibly in the areas of the sampling units, based on the description of former employees of the Conservation Unit (Rezende 2012). Despite the incident, after the result of 30 years of preservation it is considered a moderately disturbed area composed of an important forest remnant (Chiarello 2000) with an area of about 445 ha $^{2}$ (Costa et al. 2017).

The dense ombrophilous lowland forest is characterized by high temperatures and high well-distributed precipitation throughout the year (Garbin et al. 2017). The forest type is found in areas ranging from plains close to the coast to elevations between 20 to $200 \mathrm{~m}$ above sea level from Pernambuco to Rio de Janeiro (Rizzini 1997). Córrego Grande Biological Reserve is located at an elevation of $55 \mathrm{~m}$ (Costa et al. 2017). The climate of the region is humid tropical (Alvares 2013) with an average annual temperature of $23.9{ }^{\circ} \mathrm{C}$ and an average total precipitation of $1350 \mathrm{~mm}$ per year. The topography is mainly characterised by coastal tablelands with nutrient-poor soil (Peixoto et al. 2008).

\section{Data sampling}

\section{Vegetation structure}

Data collection was carried out from August 2017 to September 2018. For the sampling of vegetation, sampling plots in a fixed area were established (Mueller-Dombois \& Ellenberg 1974). The sampling units were limited to ground road and forest stands and distributed in the interior of the forest and at two different edges. Three points were randomly determined with a minimum distance of $100 \mathrm{~m}$ between points in each sampling unit. At each point, four sample units with dimensions of $10 \mathrm{~m} \times 25 \mathrm{~m}\left(250 \mathrm{~m}^{2}\right)$ were distributed, equidistant at $10 \mathrm{~m}$ and systematically allocated in the direction from the edge to the interior of the remnant forest. The total area sampled corresponded to $0.9 \mathrm{ha}^{2}$.

All tree and shrub individuals or woody stratum with diameter at breast height $(\mathrm{DBH}) \geq$ $2.5 \mathrm{~cm}$ were measured. The individuals measured also included dead standings and were labelled with numbered aluminium plates.

Botanical specimens were collected and identified using reputable literature, dendrological keys and comparison with reference collections of herbariums in the region such as the Herbário Capixaba (CAP), Herbário Universidade Federal do Espírito Santo (VIES) and Herbário Reserva Natural Vale (CVRD).

The Angiosperm Phylogeny Group (APG IV 2016) was used for taxon classification. The species nomenclature and the abbreviations of the respective authors were checked according to the information available on the Missouri Botanical Garden website (www.tropicos.org) and on the lists in Flora do Brasil 2020 (www.reflora. jbrj.gov.br). 


\section{Supplementary materials}

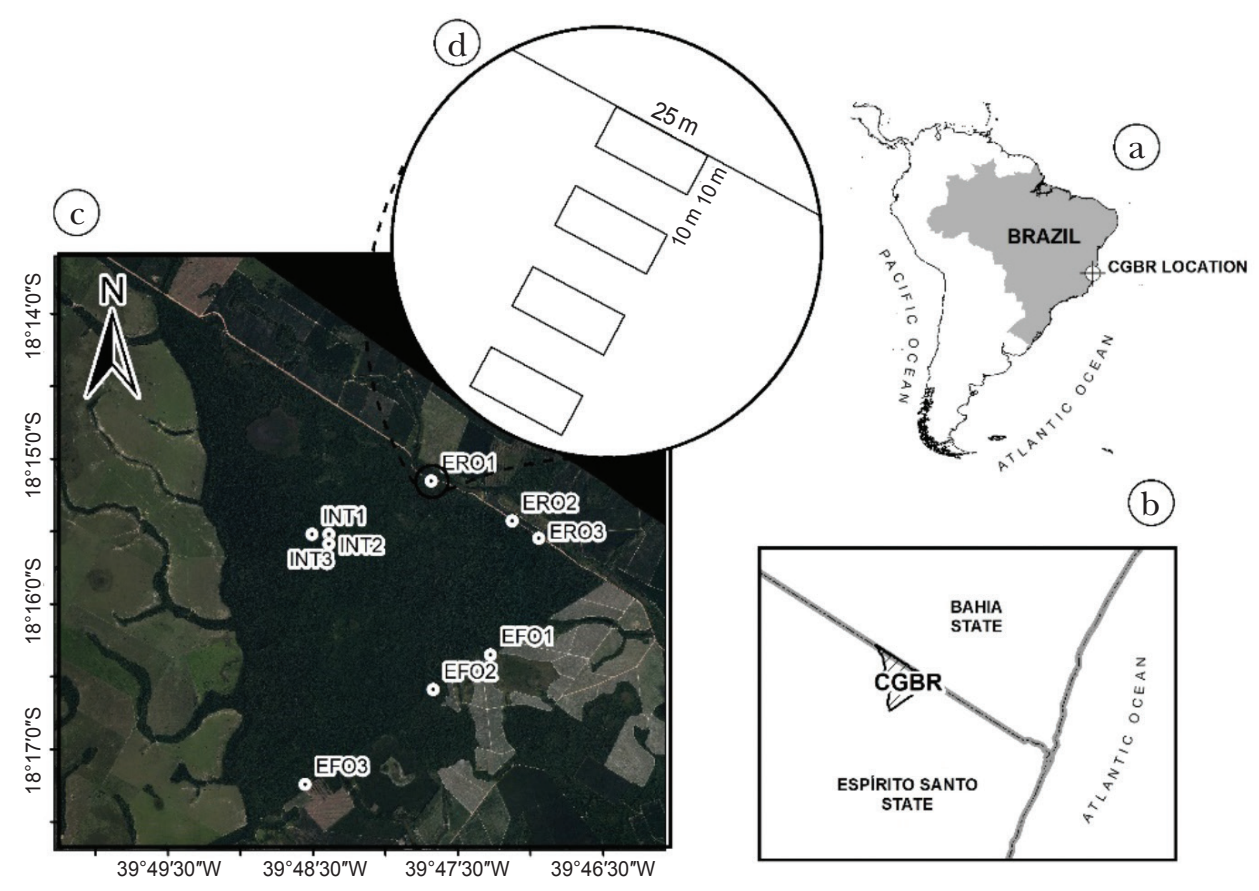

Figure 1 Location of the Córrego Grande Biological Reserve (CGBR) (a) and (b) with the allocation of sample units in the study area (c) and details of their distribution (d)

$\mathrm{ERO}=$ points that border the ground road, $\mathrm{EFO}=$ points that border the forest edge and INT = points within the forest

\section{Environmental variables}

In order to measure and capture incident light in the canopy, the method adopted from the work of Tichý (2016) by using a smartphone with an attached hemispheric lens was used to obtain hemispheric digital photographs. The photographs were recorded in the months of April during end of the period of greatest precipitation and in September during the end of the period of least precipitation of 2018. The photographs were captured at times of the day without the direct incidence of sunlight under the canopy and suitable atmospheric conditions to achieve greater uniformity of lighting. In each sampling unit, two photographs were obtained at two points, $5 \mathrm{~m}$ away from the plot boundaries to obtain an average distance per sampling unit. The images were processed using the Gap Light Analyzer Mobile software.

For soil characterisation study, soil samples were collected at five points consisting of four points at each vertex and one point at the centre of the sampling unit. In addition, three undisturbed soil samples were collected at a depth of 0-20 cm per plot in open trenches for soil density and moisture test. Subsequently, the collections were homogenised into composite. The composite was analysed for soil chemical and physical properties based the methodology proposed by EMBRAPA (2011). The physicalchemical attributes analyzed were as follows; $\mathrm{pH}$, carbon, calcium, magnesium, potassium, sodium, phosphorus, nitrogen, potential acidity, organic matter, sum of bases, cation exchange capacity, sand content, clay content, silt content, moisture and soil density.

In order to determine the penetration resistance, an impact penetrometer was used and the number of strokes reaching a soil depth of 20 $\mathrm{cm}$ was recorded. The procedure was performed at five points in each plot, one near each vertex and the other in the centre of the sample unit. The resistance to soil penetration was calculated using the equation developed by Stolf et al. (2005).

\section{Data analysis}

The phytosociological parameters used for structural description of the community were calculated as suggested by MuellerDombois and Ellenberg (1974) for the three studied environments on road, forest edge and interior 
using the R.3.2.2 software (R-Core-Team 2017). The community individuals were divided into the three different environments and distributed in diametric and hypsometric classes according to the formula proposed by Spiegel et al. (2013) .

In order to estimate the diversity and equability of species in the studied forest remnant, Shannon's diversity indices and Pielou's equitability indices (Magurran 2013) were calculated using the vegan package (Oksanen et al., 2018) of the R.3.2.2 software (R-Core-Team 2017). As the absolute density data of the study did not fulfil the assumptions of normality of residues in Shapiro-Wilk test and homogeneity of variances in Levene's homoscedasticity test, the variable was subjected to the non-parametric test of multiple comparisons in Kruskal-Wallis test to detect significant differences between the edges of the road, forest edge and the interior.

Species richness and diversities of the three sampled environments were evaluated in relation to the number of individuals and sample units, using the rarefaction and individual extrapolation curves. Species richness was built using the first Hill numbers (species richness, $q=0$ ) and diversities using Shannon's exponential indices (species diversity, $q=1$ ) (Chao et al. 2014). Extrapolations were made based on the abundance data, considering between two and three times the total sample size by types of environment (Colwell et al. 2012). Rarefaction or extrapolation curves based on individuals and sample units were calculated using the iNEXT package (Hsieh et al. 2016). Rarefaction curve was estimated as the average of 100 bootstrapping runs replicated to estimate $95 \%$ confidence intervals. Whenever the $95 \%$ confidence intervals did not overlap, the number of species differed significantly by $\mathrm{p}<0.05$ (Colwell et al. 2012). This analysis, as well as the preliminary tests of normality and homoscedasticity were carried out with the aid of the R.3.2.2 program (R-Core-Team 2017).

The species which characterized the floristic groupings for road, forest and inland edge study area were formed by the unweighted pairgroup method with arithmetic mean method. Furthermore, the indicator species analysis was performed using the combination of relative abundance values and relative frequency of species (Dufrêne \& Legendre 1997). The significance of the results obtained was verified by the Monte Carlo test, using the PC-ORD 6.08 program (McCune \& Mefford 2011).

Analysis of a non-metric multidimensional scale was performed to verify possible differences in species similarity between the plots of the three environments. Ordination was performed using the Jaccard coefficient indices taking into account qualitative and presence-absence of species and by using Bray-Curtis analysis to access the quantitative and abundance-density of individuals of the species. Multivariate similarity analysis (one-way ANOSIM) was used to ascertain differences in the composition between areas and performed using Jaccard and Bray-Curtis dissimilarity indices with distances of 9999 permutations and a significance level of 0.01 (Clarke 1993). The analysis was performed using the PAST 3.13 program (Hammer et al. 2001).

Canonical correspondence analysis was performed to investigate the relationship between abiotic variables such as canopy opening, chemical, physical and resistance to soil penetration and biotic variables such as species. The ordistep function of the vegan package was used to select the variables that best explain the species distribution (Oksanen et al. 2018) and only variables with a variance inflation factor value $<2$ were used. The significance of each abiotic variable was verified using Monte Carlo randomisations method and only species with $>10$ individuals were used. Canonical Correspondence Analysis was later performed using the autoplot function of the ggplot2 package (Hadley 2015).

\section{RESULTS}

\section{Vegetation structure}

A total of 2426 individuals were sampled where $2268(93.49 \%)$ were living sample and 158 $(6.51 \%)$. All individuals were divided into road, forest edge and interior categories (Table 1), which allowed the estimation of density at 2696 individuals $\mathrm{ha}^{-1}$ and a basal area of $29.67 \mathrm{~m}^{2} \mathrm{ha}^{-1}$. All living individuals were distributed in 69 botanical families and 147 genera (Appendix). A total of 335 species were recorded at the taxonomic levels where 89 morphotypes identified at the genus level, 38 morphotypes at the family level and 10 indeterminate morphotypes. The areas shared a total of 77 sampled species (Figure 2). 
Table 1 Vegetation structure of individuals collected from the road edge, forest edge and inside forest remnant at Córrego Grande Biological Reserve, Brazil

\begin{tabular}{|c|c|c|c|c|}
\hline & Road & Forest edge & Interior & Total \\
\hline Sampled individuals & 800 & 942 & 684 & 2426 \\
\hline Density of individuals (individual ha-1) & 2667 & 3140 & 2280 & 2696 \\
\hline Dead $(\%)$ & 5.62 & 6.68 & 7.30 & 6.51 \\
\hline Basal area $\left(\mathrm{m}^{2} \mathrm{ha}^{-1}\right)$ & 8.65 & 11.71 & 9.31 & 29.67 \\
\hline Total families (families ha-1) & 56 & 56 & 53 & 77 \\
\hline Total species (species ha ${ }^{-1}$ ) & 186 & 227 & 198 & 373 \\
\hline Shannon Diversity (nats ind ${ }^{-1}$ ) & 4.45 & 4.55 & 4.62 & 4.86 \\
\hline Pielou equability & 0.87 & 0.86 & 0.89 & 0.84 \\
\hline
\end{tabular}

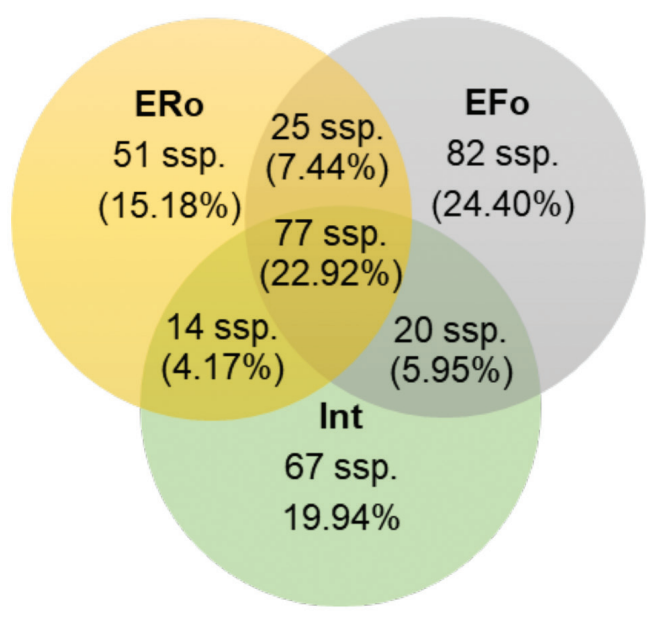

Figure 2 Venn diagram of the species sharing the different environments of the dense ombrophilous lowland forest in the Córrego Grande Biological Reserve $\mathrm{ERo}=$ road edge, $\mathrm{EFo}=$ forest edge and $\mathrm{Int}=$ interior

The families with the greatest richness in species and morphotypes were Fabaceae (50 species) and Myrtaceae (40 species). The three species which presented the highest importance values (IVs) of the woody stratum for the roadside area were Astrocaryum aculeatissimum (11.72\%), Eriotheca macrophylla (11.51\%) and Eschweilera ovata (10.72\%). For the forest edge, Protium heptaphyllum (14.39\%) and Macrolobium latifolium (12.35\%), Guapira opposita (12.09\%) had the highest IV values. For the interior, A. aculeatissimum (13.33\%), Joanesia princeps $(12.39 \%)$ and Virola officinalis $(10.65 \%)$ showed the highest IV values (Appendix).

The diametric distribution presented a J-inverted pattern for all areas. The first two classes containing individuals with $\mathrm{DBH}$ of 2.5-20.9 cm, consisted $93.0 \%$ of the individuals in road edge, $92.2 \%$ of the individuals in forest edge and $91.5 \%$ of the individuals in interior. It is noteworthy that individuals with a $\mathrm{DBH}$ less than $5 \mathrm{~cm}$ accounted for approximately $41 \%$ (989 individuals) of all sampled specimens. The mean height of the individuals at the roadside was $6.8 \mathrm{~m}$, the forest edge was $8.0 \mathrm{~m}$ and inside the forest was $6.2 \mathrm{~m}$. The maximum heights of $17.0 \mathrm{~m}$ at the roadside, $50.0 \mathrm{~m}$ in the forest edge and $30.0 \mathrm{~m}$ inside the forest respectively. The distribution of individuals by hypsometric classes showed that first three classes concentrated $94.1 \%$ at the roadside, $83.4 \%$ in the forest edge and $93.8 \%$ inside the forest of all specimens inventoried. The second hypsometric class ( 4.3 to $8.4 \mathrm{~m}$ ) gathered the highest percentages of individuals at $55.7 \%$ at the roadside, $45.1 \%$ in the forest edge and $42.3 \%$ inside the forest (Figure 3 ).

The Kruskal-Wallis nonparametric test revealed significant differences between the studied environments in relation to the density of the individuals in forest edge and interior 


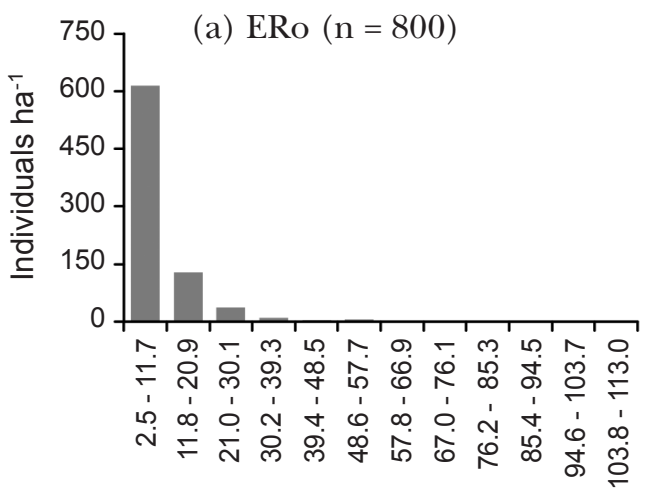

Diameter class $(\mathrm{cm})$
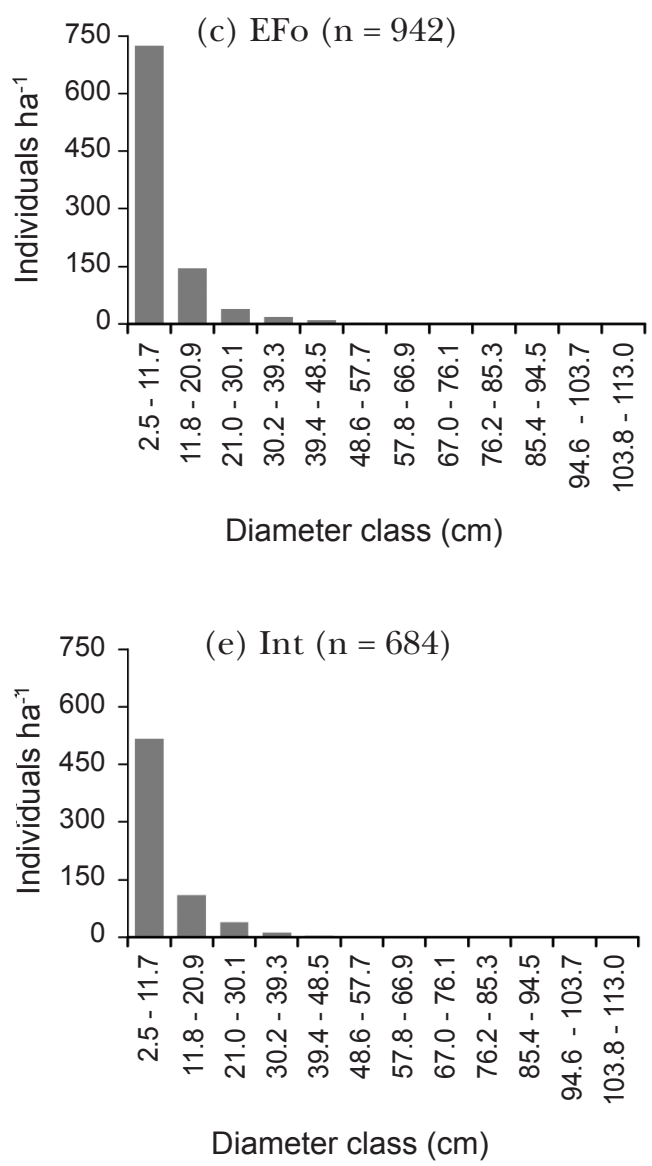
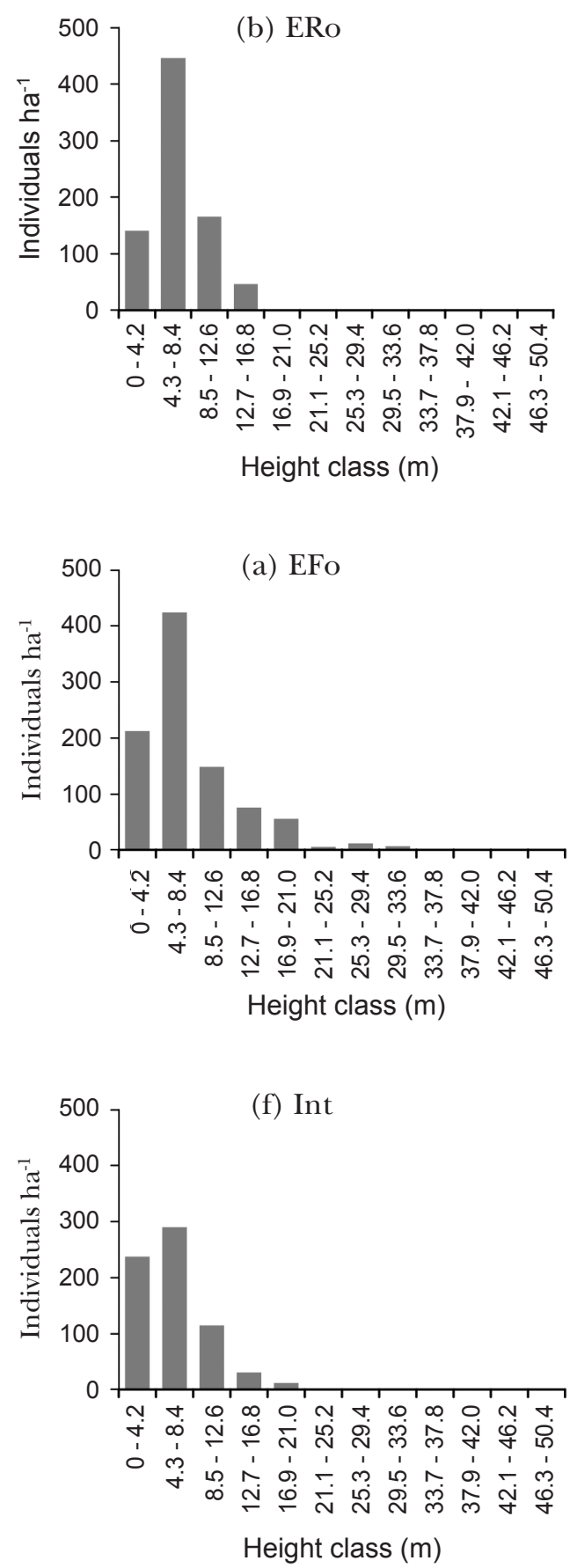

Figure 3 Distribution of individuals of the woody stratum by diameter and height classes at the roadside (ERo), forest edge (EFo) and interior (Int) sampled in remnants of dense ombrophilous lowland forest in the Córrego Grande Biological Reserve

(Kruskal-Wallis $=0.023, \mathrm{p}<0.05)$ and between forest edge and roadside (Kruskal-Wallis $=0.321$, $\mathrm{p}<0.05)$.

The analysis of a non-metric multidimensional scale revealed the formation of groups with greater similarity of species (Figure 4) showing the composition of the species for the three areas varied significantly between them for the two indices evaluated (ANOSIM: Jaccard $\mathrm{R}=0.22$, $\mathrm{p}<0.01$, Bray Curtis $\mathrm{R}=0.27, \mathrm{p}<0.01$ ).

The interior of the remnant forest showed greater diversity of species and differed from the edges of the roadside and the forest based on the number of individuals (Figure 5). In contrast, the forest edge differed from the roadside and the interior of the remnant based on the sample 

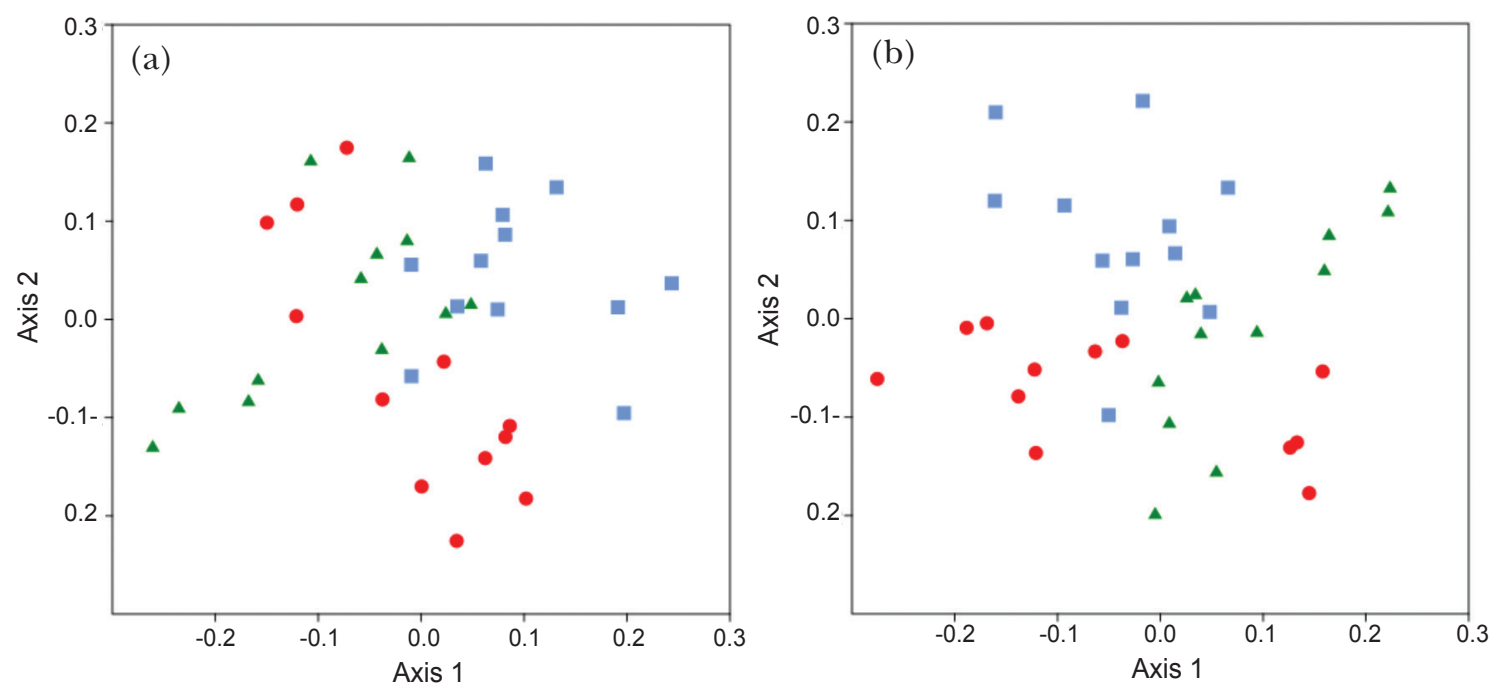

Figure 4 Non-metric multidimensional scale based on species composition among the plots of the three studied environments using ordination by the Jaccard Index (a) and Bray Curtis (b) at Córrego Grande Biological Reserve, Brazil

Circle $=$ roadside, Triangle $=$ forest edge, Square $=$ interior

units, which showed lower diversity of species (Figure $5 \mathrm{a}$ and $5 \mathrm{~b}$ ). The forest edge and the inside forest environments showed the highest species richness for the number of individuals (Figure 5c). Similar richness patterns were observed between the inside forest and forest edge environments but there were differences between these environments with the roadside (Figure 5d).

According to the indicator species analysis, three species obtained significantly different distribution $(\mathrm{p}<0.05)$ with an indicator value (VI) greater than $50 \%$. E. ovata (VI $=57.5 \%$, $\mathrm{p}$-value $=0.0016)$ was chosen as an indicator of the roadside, while $M$. latifolium (VI $=75.6 \%$, p-value $=0.0004)$ and P. heptaphyllum $(\mathrm{VI}=53.3 \%$, p-value $=0.0030)$ were forest border indicator species.

\section{Vegetation-environment relationship}

The two axes of the canonical correspondence analysis explained $56.5 \%$ of the variation of species and sampling units as a function of environmental variables (Axis $1=33.2 \%$, Axis $2=23.3 \%)$. The variables humidity and penetration resistance showed strong correlation $(p>0.5)$ with axis 2. Variables such as potassium, sodium and cation exchange capacity also indicated correlation with the axis, where sodium and cation exchange capacity were negatively correlated. The same variables correlated in axis 2 and for axis 1 , but with a weaker correlation (Figure 6).
The plots located at the roadside (Rows 1 to 12) presented higher values of cation exchange capacity and sodium but low values for the other variables (Figure 6a). The dominant species in this group were Astrocaryum aculeatissimum, Trichilia lepidota, Astronium graveolens and Eschweilera ovata, which were considered indicator species of this environment (Figure 6b). Half of the forest edge sampling units (rows 13 to 24) presented higher values of humidity and penetration resistance with intermediate values of sodium and cation exchange capacity (Figure 6a). Most of the plots located inside the forest were in the central part of the diagram, showing intermediate values for all variables with the exception of Rows 31 and 32 (Figure 6a).

The study showed E. macrophylla, J. princeps and Pterocarpus rohrii were more strongly associated with the variables of humidity and penetration resistance. Virola officinalis was associated with higher levels of potassium. On the other hand, Lacistema robustum, Eugenia astringens and Tabernaemontana salzmannii were strongly associated with cation exchange capacity and sodium.

\section{DISCUSSION}

\section{Vegetation structure}

The results showed that fragmentation was the conditioning factor of the edge effect. It influenced the structure and distribution of plant 

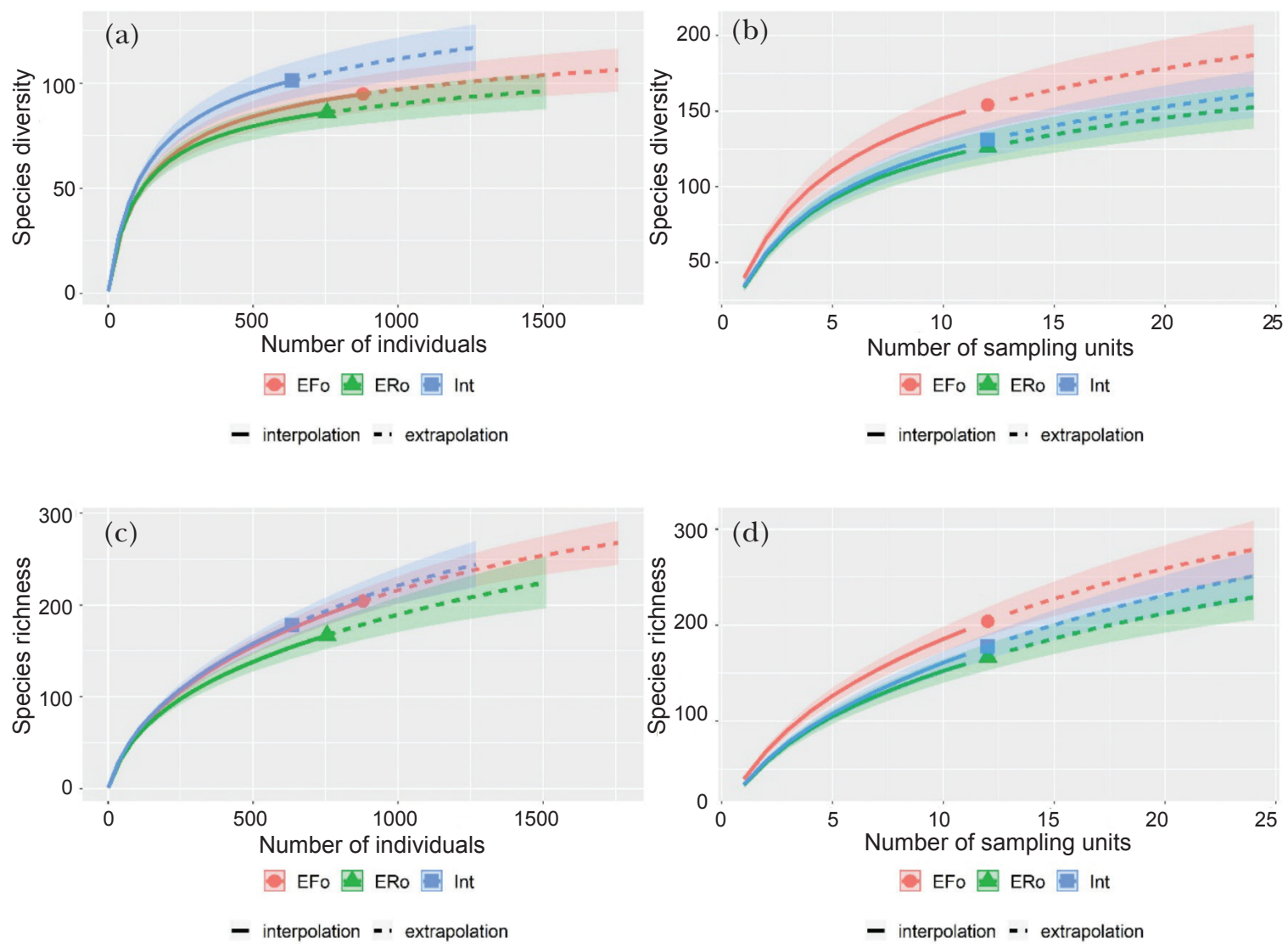

Figure 5 Rarefaction (solid line) and extrapolation curves (dashed lines) based on the number of individuals (a) and (c), sample units (b) and (d), species diversity and species richness for the three different areas sampled at the Córrego Grande Biological Reserve, Brazil.

The rarefaction and extrapolation curves represent mean values and standard deviation with $95 \%$ confidence intervals

$\mathrm{EFo}=$ forest edge, $\mathrm{ERo}=$ roadside and Int $=$ interior

community species and corroborated with the existing literature, where intense edge effects were manifested in the $50 \mathrm{~m}$ margins of the forest remnants (Murcia 1995, Dias et al. 2019). This is a pattern commonly observed in forest remnants with distinct perturbation histories. It reinforces the relevance of environmental differences between the edge and interior of forest remnants as predictors for communities of tree species (Pscheidt 2018), which affects the composition of species and vegetation structure (Dias et al. 2019).

The estimated number of species per hectare in this study was 373 species ha $^{-1}$ and near to values observed in other studies conducted in dense ombrophilous forest (Magnago et al. 2014, Saiter \& Thomaz 2014). The conditions of which edge environments were subjected to could be the main reason for the high values of diversity and equability found in the studied environments and also shown by the indices and in the rarefaction and extrapolation curves. Such environments were more exposed to external disturbances and generally had a greater diversity and density of species (Fortin 1994).

Matrices comprised of different characteristics have different impacts on the recruitment and establishment of certain plant species (Nascimento \& Laurance 2006). Thus, the different types of matrices related to the studied environments such as road and forest stands could influence the establishment and generated different patterns of species composition in the environments (Murcia 1995, Lima-Ribeiro 2008). Thus, the fragments of the surrounding matrix should be managed to minimize the edge effect and to improve connectivity (Ribeiro et al. 2009, Yoshida et al. 2019).

The two edge environments studied showed a higher abundance of individuals when compared to the interior of the remnant where the forest edge showed the highest species 


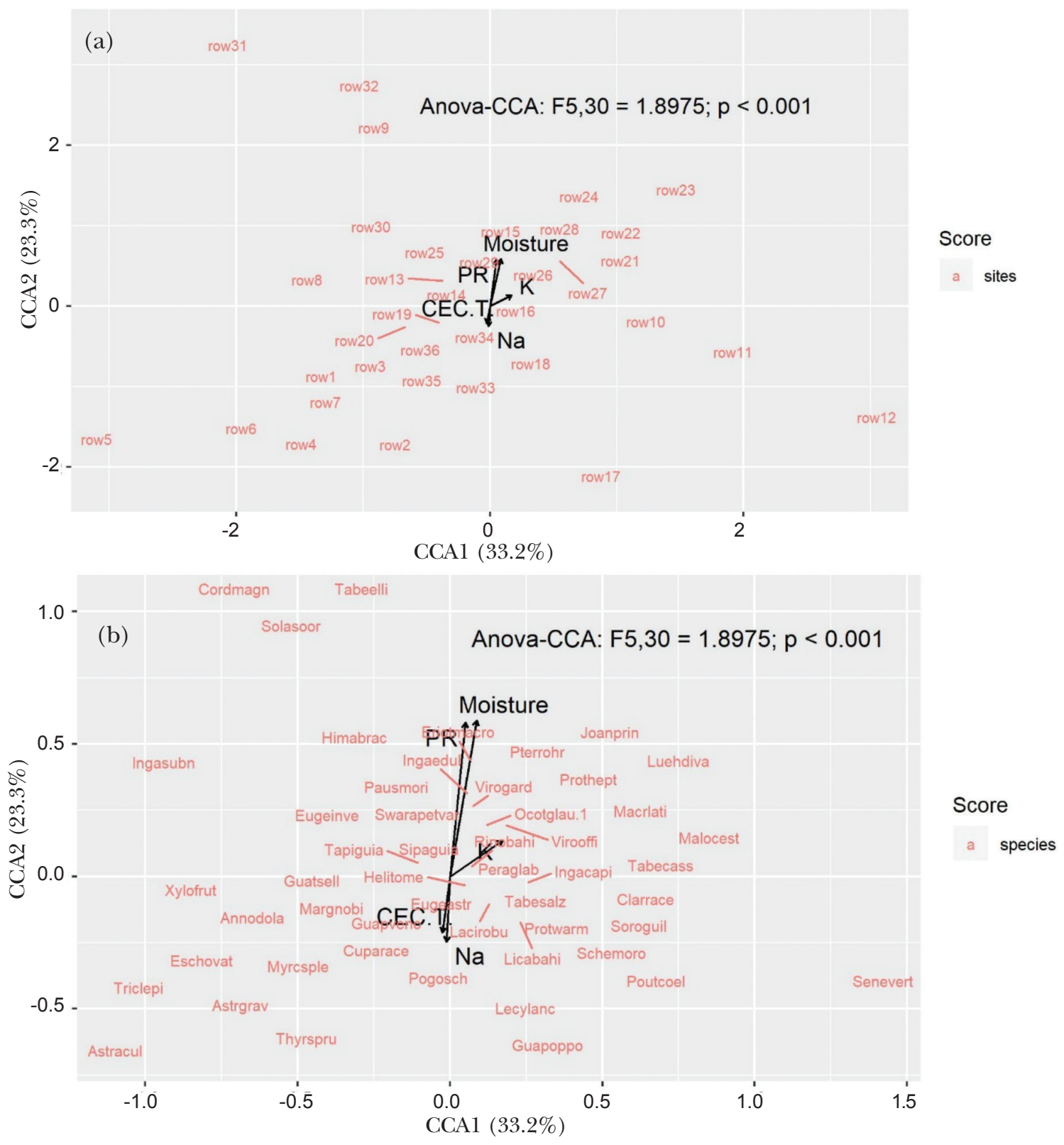

Figure 6 Canonical correspondence analysis (CCA) with the ordination of the 36 sample units (a) and the species of greatest abundance (b) as a function of environmental variables

Annodola $=$ Annona dolabripetala, Astracul $=$ Astrocaryum aculeatissimum, Astrgrav $=$ Astronium graveolens, Clarrace $=$ Clarisia racemose, Cordmagn $=$ Cordia magnoliifolia, Cuparace $=$ Cupania racemose, Eriotmacro $=$ Eriotheca macrophylla, Eschovat $=$ Eschweilera ovata, Eugeastr $=$ Eugenia astringens, Eugeinve $=$ Eugenia inversa, Guapoppo $=$ Guapira opposite, Guapveno $=$ Guapira venosa, Guatsell $=$ Guatteria sellowiana, Helitome $=$ Helicostylis tomentos, Himabrac $=$ Himatanthus bracteatus, Ingacapi $=$ Inga capitate, Ingaedul $=$ Inga edulis, Ingasubn $=$ Inga subnuda, Joanprin $=$ Joannesia princeps, Lacirobu $=$ Lacistema robustum, Lecylanc $=$ Lecythis lanceolate, Licabahi $=$ Licaria bahiana, Luehdiva $=$ Luehea divaricate, Macrlati $=$ Macrolobium latifolium, Malocest $=$ Malouetia cestroides, Margnobi $=$ Margaritaria nobilis, Myrcsple $=$ Myrcia splendens, Ocotglau $=$ Ocotea glauca, Pausmori $=$ Pausandra morisiana, Peraglab $=$ Pera glabrata $;$ Pogosch $=$ Pogonophora schomburgkiana, Poutcoel = Pouteria coelomatica, Prothept $=$ Protium heptaphyllum, Protwarm $=$ Protium warmingianum, Pterrohr $=$ Pterocarpus rohrii, Rinobahi $=$ Rinorea bahiensis, Schemoro $=$ Didymopanax morototoni, Senevert $=$ Senefeldera verticillate, Sipaguia $=$ Siparuna guianensis, Solasoor $=$ Solanum sooretamum, , Soroguil = Sorocea guilleminiana, Swarapetvar $=$ Swartzia apetala var. apetala , Tabecass $=$ Tabebuia cassinoides, Tabeelli $=$ Tabebuia elliptica, Tabesalz $=$ Tabernaemontana salzmannii, Tapiguia $=$ Tapirira guianensis, Thyrspru $=$ Thyrsodium spruceanum, Triclepi $=$ Trichilia lepidota, Virogard $=$ Virola gardneri, Virooffi $=$ Virola officinalis, Xylofrut $=$ Xylopia frutescens 
richness. Approximately $60 \%$ of the total species sampled were found in only one of the three environments, which inferred that most species had their specific habitats or were restricted by other habitats. The three environments showed to have unique species. Thus, preservation of the remnant forest is important with the purpose to protect species against extinction due to the different environment conditions in forests with fragmentation situations (Pscheidt et al. 2018).

The high concentration of individuals within the first diametric classes revealed the presence of high number of young specimens in the community, suggesting good reproduction rate for new individuals. In this manner, the community achieved self-sustainability as new individuals present in the understory would be able to replace individuals which had already reach maximum maturity (Colonetti et al. 2009). The small number or absence of individuals in the higher diameter classes might be related to mortality caused by the edge effect (Laurance et al. 2000) as well as to the high abundance of small-sized species such as Tabernaemontana salzmannii.

The percentage of dead trees at the edges were lower when compared to the interior of the remaining and mostly consisted of small size individuals. Studies conducted in dense ombrophilous forest have shown accelerated mortality of trees in the edge areas, especially in the first years after fragmentation and large trees were the most affected ones (Laurance et al. 2000). In addition, the lower mortality of the species present in the edges was caused by their generalist nature, enabling them to adapt to these edge environment changes caused by the fragmentations.

Astrocaryum aculeatissimum (Family Arecaceae), a tree from the largest indicator value species of the forest edge and a great importance species in the studied remnant forest (Costa et al. 2017), depended on medium and large mammals for its seed dispersal (Zucaratto \& Pires 2015). In fragmented forests, these animals were rare or absent, causing reduced distribution of the A. aculeatissimum seedlings (Donatti et al. 2009) and resulting in an aggregate spatial distribution of these palm trees (Zucaratto \& Pires 2015). In addition, the regrowth capacity of these species also depended on its persistence and survival ability even in the absence of the seed dispersing agents (Bond \& Midgley
2001). This partly explained the differences in relationship observed in the density between the forest edge with the interior, the height between the forest edge with the interior and the differences between the forests edges with other environments studied in the remnant forest.

Some of the rainforests in the world consist of secondary forests and their importance will continue to increase (Chazdon 2014, Lohbeck et al. 2016). Therefore, in order to maintain the high species diversity and richness in these regions, conservation efforts should ensure the forest remnants continue to exist, maintain a higher proportion of biodiversity and not subjected to additional fragmentation. In tropical regions, anthropic activities had caused loss of large forest areas, the protection of these areas remained the focal strategy to reduce deforestation and species extinction (Joppa et al. 2008).

The results from this study emphasized the need for site-specific recommendations on the management of the forest rather than generalized recommendations. It was due to the substantial influences of microclimate on the structure of the forest edge. When site-specific managements were in place, only then the microclimate, functioning and biodiversity of the edge of the forest could be conserved on a local scale (Meeussen et al. 2020). Conservation actions beyond the boundaries of these fragments were of paramount importance for the protection of these habitats and the maintenance of biodiversity.

\section{Vegetation-environment relationship}

Environmental variables such as moisture, penetration resistance, cation exchange capacity and sodium and potassium levels were the main factors which explained the differences between the studied environments and these parameters determined the composition of the community (Rodrigues et al. 2020). The higher humidity values of the sample units within the forest edge were probably related to the higher presence of clay in the ground (Corrêa Neto et al. 2018) and consequently caused greater resistance to penetration compared to other environments (Mendes et al. 2016).

Some species were concentrated in the centre of the diagram, presenting low canonical values for the two ordination axes and therefore be 
concluded that these species present greater plasticity (Souza et al. 2017). Unlike these species, Eschweilera ovata an indicator species of the roadside which appeared far from the centre of the diagram was classified for tropical forests in the North of the Espírito Santo as late secondary forest species (Jesus \& Rolim 2005). However, this species was also found in different successional stages, indicating its potential to adapt to different environments (Magnago et al. 2014).

Previous study showed the microclimate at the forest edge differed from that of the interior of the forest, in addition to other attributes such as physical and chemical soil properties (Pinto et al. 2010). These changes in environmental variables along the sample units probably also promoted high species turnover among the studied environments which was shown with the variation in species composition. The heterogeneity detected supported the different species associations with the different types of environments (Schmitz et al. 2020).

\section{ACKNOWLEDGEMENTS}

This study was financed in part by the Coordenação de Aperfeiçoamento de Pessoal de Nível SuperiorBrasil (CAPES) (Finance Code 001) and the Fundação de Amparo à Pesquisa e Inovação do Espírito Santo (FAPES) (Edital Universal-No. 03/2017 (T.O.169 - SIAFEM: 80709605/18). The authors thanked UFES and NUPEMASE for their logistic support. Their sincere appreciation to Mr. Ademar Silva and friends for sample collection and field assistance, Mr. Geovane S. Siqueira for his assistance in botanical identification at Vale's herbarium (CVRD) and Mr. Gabriel Resende for the logistical support and permission to conduct research at Córrego Grande Biological Reserve.

\section{REFERENCES}

Alvares CA, Stape Jl, Sentelhas PG et al. 2013. Köppen's climate classification map for Brazil. Meteorologische Zeitschrift 22: 711-728. https://doi. org/10.1127/0941-2948/2013/0507

APG IV. 2016. An update of the Angiosperm Phylogeny Group classification for the orders and families of flowering plants: APG IV 2016. Botanical Journal of the Linnean Society of London 181: 1-20. https:/ / doi. org/10.1111/boj.12385

Bond WJ \& Midgley JJ. 2001. Ecology of sprouting in woody plants: the persistence niche. Trends in Ecology $\mathcal{E}^{\circ}$ Evolution 16: 45-51. https://doi.org/10.1016/S01695347(00) 02033-4
BRASIL 1989. Decreto n. 97.657, de 12 de abril de 1989. Cria a Reserva Biológica do Córrego Grande. Diário Oficial [da] República Federativa do Brasil, Brasília, DF, 12 abr. 1989. https://www.planalto.gov.br/ccivil_03/ decreto/1980 1989/d97657.htm

Chazdon RL 2014. Second Growth: the Promise of Tropical Forest Regeneration in an Age of Deforestation. University of Chicago Press, London.

Chao A, Gotelli NJ, Hsieh TC et al. 2014. Rarefaction and extrapolation with Hill numbers: a framework for sampling and estimation in species diversity studies. Ecological Monographs 84: 45-67. https://doi. org/10.1890/13-0133.1

Chiarello AG. 2000. Influência da caça ilegal sobre mamíferos e aves das matas de tabuleiro do norte do estado do Espírito Santo. Boletim do Museu de Biologia Mello Leitão 11: 229-247.

CLARKE KR. 1993. Non-parametric multivariate analyses of changes in community structure. Australian Journal of Ecology 18: 117-143. https://doi. org/10.1111/j.1442-9993.1993.tb00438.x

Colonetti S, Citadini-Zanette V, Martins R et al. 2009. Florística e estrutura fitossociológica em floresta ombrófila densa submontana na barragem do rio São Bento, Siderópolis, Estado de Santa Catarina. Acta Scientiarum. Biological Sciences 31: 397-405. 10.4025/ actascibiolsci.v31i4.3345

Colwell RK, Chao A, Gotelli NJ et al. 2012. Models and estimators linking individual-based and samplebased rarefaction, extrapolation and comparison of assemblages. Journal of Plant Ecology 5: 3-21. https:/ / doi.org/10.1093/jpe/rtr044

CorrêA Neto TA, Anjos LHC, Camara R et AL. 2018. Relação fauna do solo-paisagem em plantio de eucalipto em topossequência. Floresta 48: 213-224. http:/ /dx.doi. org/10.5380/rf.v48i2.55041

Costa MB, Menezes LFT \& Nascimento MT. 2017. Postfire regeneration in seasonally dry tropical forest fragments in southeastern Brazil. Anais da Academia Brasileira de Ciencias 89: 2687-2695. https://doi. org/10.1590/0001-3765201720160728

Dias PB, Moreira LN, Silva GF et AL. 2019. Riqueza, estrutura e relações ambientais em uma Floresta Nacional no Sudeste do Brasil. Revista Brasileira de Ciências Agrárias 14: 6897. https://doi.org/10.5039/agraria. v14i4a6897

Donatti CI, Guimarães PR \& Galetti M. 2009. Seed dispersal and predation in the endemic Atlantic rainforest palm Astrocaryum aculeatissimum across a gradient of seed disperser abundance. Ecological Research 24: 1187. https://doi.org/10.1007/s11284-009-0601-x

Dufrêne M \& Legendre P. 1997. Species assemblages and indicator species: the need for a flexible asymmetrical approach. Ecological monographs 67: 345-366. https:/ / doi.org/10.1890/0012-9615(1997)067[0345:SAAIST unette2.0.CO;2

Empresa Brasileira de Pesquisa Agropecuária - EMBraPA. 2011. Manual de métodos de análise de solos. 2.ed. Embrapa Solos, Rio de Janeiro.

Fortin MJ. 1994. Edge detection algorithms for twodimensional ecological data. Ecology 75: 956-965. https://doi.org/10.2307/1939419 
Garbin ML, Saiter FZ, Carrijo TT et al. 2017. Breve histórico e classificação da vegetação capixaba. Rodriguesia 68: 1883-1894. https://doi.org/10.1590/21757860201768521

HADLEY WR. 2015. ggplot2 package: an implementation of the grammar of graphics. http:/ /ggplot2.org

Hammer $\varnothing$, HarPER DA \& RyAn PD. 2001. PAST: Paleontological statistics software package for education and data analysis. Palaeontologia Electronica 4: 9. http:/ / palaeoelectronica.org/2001 1/past/issue1 01.htm

Harper KA, Macdonald SE, Burton PJ et al. 2005. Edge influence on forest structure and composition in fragmented landscapes. Conservation Biology 19: 768-782. https://doi.org/10.1111/j.15231739.2005.00045.x

Hsien TC, MA KH \& CHAo A. 2016. iNEXT: iNterpolation and EXTrapolation for species diversity. R Package Version 2: 1-18. https://cran.r-project.org/web/packages/ iNEXT/iNEXT.pdf

Jesus RM \& Rolim SG. 2005. Fitossociologia da Mata Atlântica de Tabuleiro. Documento SIF 19. Sociedade de Investigações Florestais, Viçosa.

Joppa LN, LOARIE SR \& PIMm SL. 2008. On the protection of "protected areas". Proceedings of the National Academy of Sciences 105: 6673-6678. https:/ / doi.org/10.1073/ pnas.0802471105

Laurance WF, Delamônica P, Laurance SG et al. 2000. Rainforest fragmentation kills big trees. Nature 404: 836-836. https://doi.org/10.1038/35009032

LAURANCE WF. 2008. Theory meets reality: how habitat fragmentation research has transcended island biogeographic theory. Biological Conservation 141: 1731-1744. https://doi.org/10.1016/j. biocon.2008.05.011

Lima-Ribeiro MS. 2008. Efeitos de borda sobre a vegetação e estruturação populacional em fragmentos de Cerradão no Sudoeste Goiano, Brasil. Acta Botanica Brasilica 22: 535-545. https://doi.org/10.1590/ S0102-33062008000200020

Lohbeck M, Bongers F, Martinez-Ramos M et al. 2016. The importance of biodiversity and dominance for multiple ecosystem functions in a human-modified tropical landscape. Ecology 97: 2772-2779. https:// doi.org/10.1002/ecy.1499

Magnago LFS, Edwards DP, Edwards FA et al. 2014. Functional attributes change but functional richness is unchanged after fragmentation of Brazilian Atlantic forests. Journal of Ecology 102: 475-485. https://doi.org/10.1111/1365-2745.12206

Magurran AE. 2013. Medindo a Diversidade Biológica. UFPR, Curitiba.

Mccune B \& Mefford MJ. 2011. PC-ORD for Windows: multivariate analysis of ecological data, version $6.08 . \mathrm{MjM}$ Software Design, Oregon.

Meeussen C, Govaert S, Vanneste T et al. 2020. Structural variation of forest edges across Europe. Forest Ecology and Management 462: 117929. https://doi. org/10.1016/j.foreco.2020.117929

Mendes PGA, Silva MAM, Guerra TNF et al. 2016. Dynamics and edge effect of an Atlantic Forest fragment in Brazil. Floresta e Ambiente 23: 340-349. https://doi. org $/ 10.1590 / 2179-8087.064713$
Mittermeier RA, Gil PR, Hoffmann M et AL. 2004. Hotspots Revisited:Earth's Biologically Richest and MostEndangered Terrestrial Ecoregions. Cemex, Washington DC.

Mueller-Dombois D \& Ellenberg H. 1974. Aims and methods vegetation ecology. John Wiley, New York.

Murcia C. 1995. Edge effects in fragmented forest: implications for conservation. Trends Ecology and Evolution 10: 58-62. https://doi.org/10.1016/S0169$5347(00) 88977-6$

Nascimento HE \& Laurance WF. 2006. Efeitos de área e de borda sobre a estrutura florestal em fragmentos de floresta de terra-firme após 13-17 anos de isolamento. Acta Amazonica 36: 183-192. https:/ / doi. org/10.1590/S0044-59672006000200008

Oksanen J, Blanchet FG, Friendly M et al. 2018.Vegan: Community Ecology Package. R package version 2.5-2. 2018. https:/ /CRAN.R-project.org/package=vegan

Peixoto AL, Silva IM, Pereira OJ et al. 2008. Tabuleiro Forests North of the Rio Doce: Their Representation in the Vale do Rio Doce Natural Reserve, Espírito Santo, Brazil. Memoirs of the New York Botanical Garden 100: 319-350.

Pinto SR, Mendes G, Santos AM et al. 2010. Landscape attributes drive complex spatial microclimate configuration of Brazilian Atlantic forest fragments. Tropical Conservation Science 3: 389-402. https:/ / doi. org/10.1177/194008291000300404

Pscheidt F, Higuchi P, Silva ACD et Al. 2018. Efeito de borda como fonte da heterogeneidade do componente arbóreo em uma floresta com araucárias no sul do Brasil. Ciência Florestal 28: 601-612. https://doi. org/10.5902/1980509832046

R Core Team. 2017. R: a language and environment for statistical computing. R Foundation for Statistical Computing. Vienna, Austria. https://www.R-project. org/

Rezende CL, Scarano FR, Assad ED et al. 2018. From hotspot to hopespot: an opportunity for the Brazilian Atlantic Forest. Perspectives in Ecology and Conservation 16: 208 214. https://doi.org/10.1016/j.pecon.2018.10.002

Rezende GF. 2012. Processos de cooperação entre unidades de conservação e empresas: O caso da Reserva Biológica do Córrego Grande - Conceição da Barra - Norte do ES. Dissertação (Mestrado em Ciência Ambiental). Universidade Federal Fluminense, Niterói.

Ribeiro MC, Metzger JP, Martensen AC et al. 2009. The Brazilian Atlantic Forest: how much is left, and how is the remaining forest distributed? Implications for conservation. Biological Conservation 142: 1141-1153. https://doi.org/10.1016/j.biocon.2009.02.021

Rizzini CT 1997. Tratado de fitogeografia do Brasil. $2^{2}$ Edição. Âmbito Cultural Edições Ltda, Rio de Janeiro.

Rodrigues AC, Villa PM, Ali A et Al. 2020. Fine-scale habitat differentiation shapes the composition, structure and aboveground biomass but not species richness of a tropical Atlantic forest. Journal of Forestry Research 31: 1599-1611. https://doi.org/10.1007/s11676019-00994-x

SAIter FZ \& Thomaz LD. 2014. Revisão da lista de espécies arbóreas do inventário de Thomaz \& Monteiro (1997) na Estação Biológica de Santa Lúcia: o mais importante estudo fitossociológico em florestas 
montanas do Espírito Santo. Boletim do Museu de Biologia Mello Leitão 34: 101-128.

Schmitz D, Schaefer CER, Putzke J et al. 2020. How does the pedoenvironmental gradient shape non-vascular species assemblages and community structures in Maritime Antarctica? Ecological Indicators 108: 105726. https://doi.org/10.1016/j.ecolind.2019.105726

Souza RF, Machado SA, Galvão F et al. 2017. Effect of environmental variables in the distribution of tree species in the Iguaçu National Park. Revista Árvore 41: 6. https://doi.org/10.1590/180690882017000600009

Spiegel MR, Schiller JJ \& Srinivasan R. 2013. Probability and statistics. McGraw-Hill, New York. eISBN: 97800717955860071795588

Stolf R, Reichardt K \& Vaz CM. 2005. Response to "Comments on 'simultaneous measurement of soil penetration resistance and water content with a combined penetrometer-TDR moisture probe' and 'a dynamic cone penetrometer for measuring soil penetration resistance'". Soil Science Society of America Journal 69: 927-929. https://doi.org/10.2136/ sssaj2005.0927

TICHÝ L. 2016. Field test of canopy cover estimation by hemispherical photographs taken with a smartphone.
Journal of Vegetation Science 27: 427-435. https://doi. org $/ 10.1111 /$ jvs.12350

Wekesa C, Kirui BK, Maranga EK et al. 2019. Variations in forest structure, tree species diversity and above-ground biomass in edges to interior cores of fragmented forest patches of Taita Hills, Kenya. Forest Ecology and Management 440: 48-60. https:// doi.org/10.1016/j.foreco.2019.03.011

Yoshida T, Hasegawa M, Ito MT et al. 2019. Litter decomposition on forest roads versus inside tropical rainforests in Sabah, Malaysia. Journal of Tropical Forest Science 31: 108-113. https://doi. org/10.26525/jtfs2019.31.1.10.81.13

Zhang ZD \& ZANG RG. 2011. Relationship between species richness of plant functional groups and landscape patterns in a tropical forest of Hainan Island, China. Journal of Tropical Forest Science 3: 289-298. https://www.jstor.org/stable/23616973

Zucaratto R \& Pires ADS. 2015. Local extinction of an important seed disperser does not modify the spatial distribution of the endemic palm Astrocaryum aculeatissimum (Schott) Burret (Arecaceae). Acta Botanica Brasilica 29: 244-250. https://doi. org/10.1590/0102-33062015abb0008 


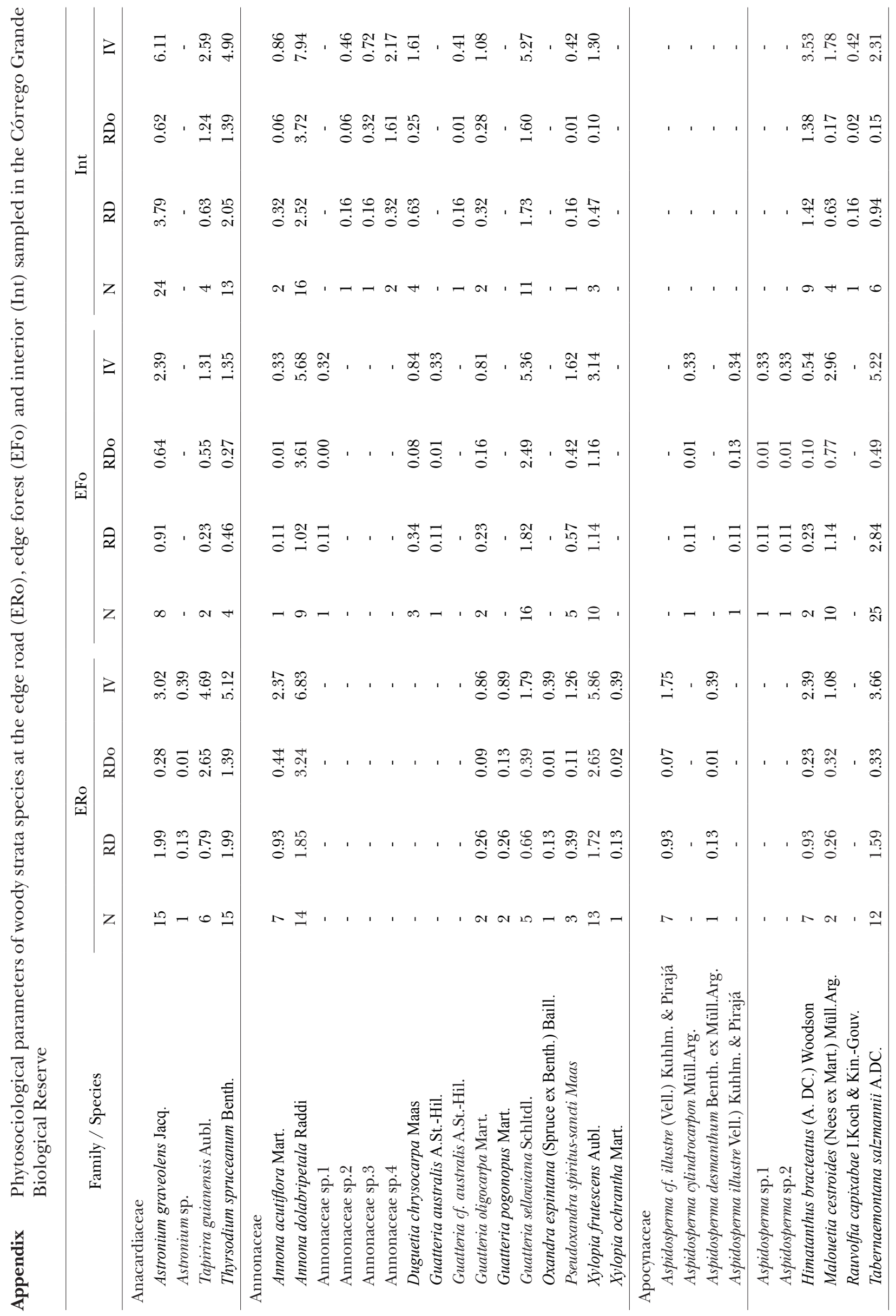




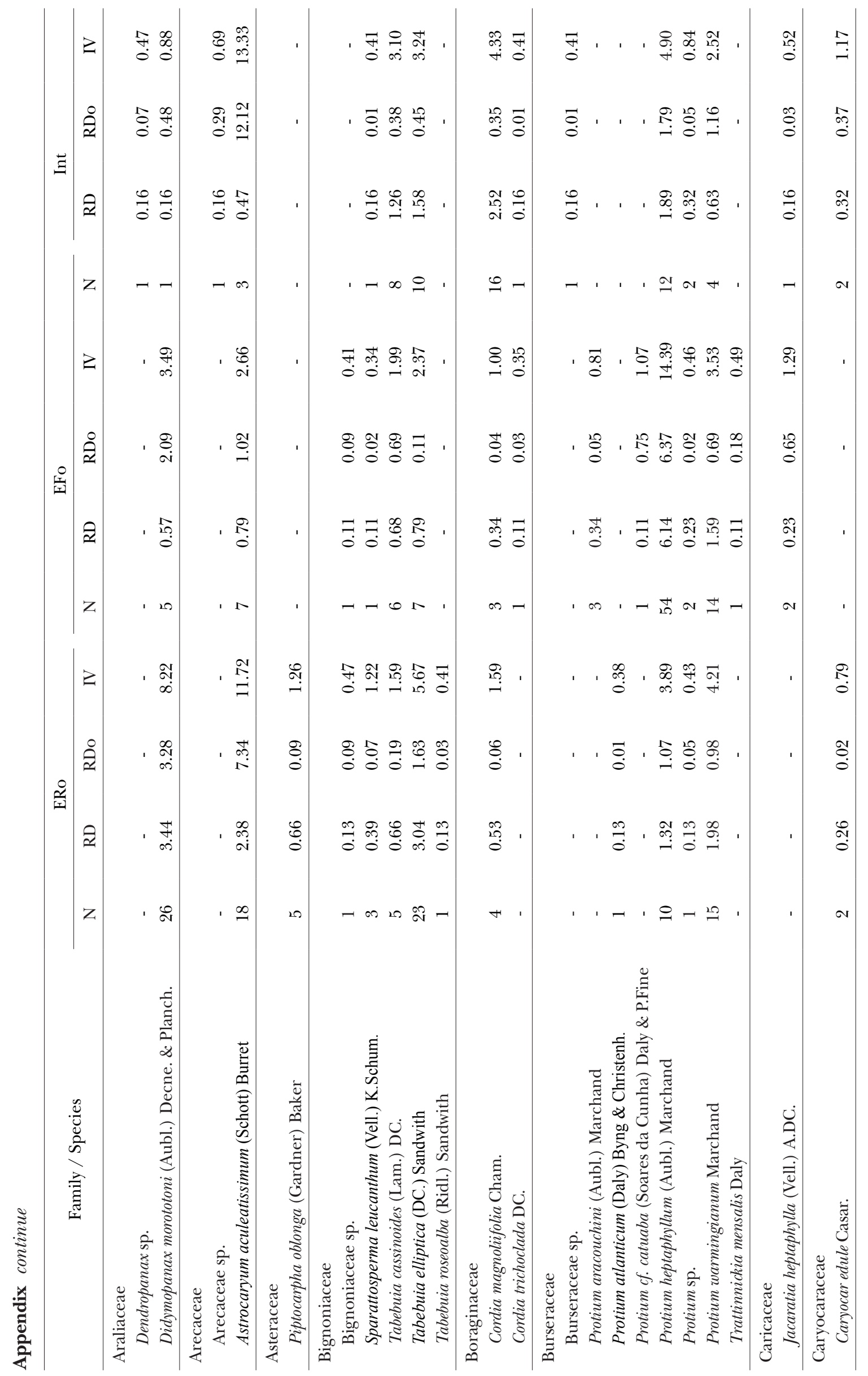




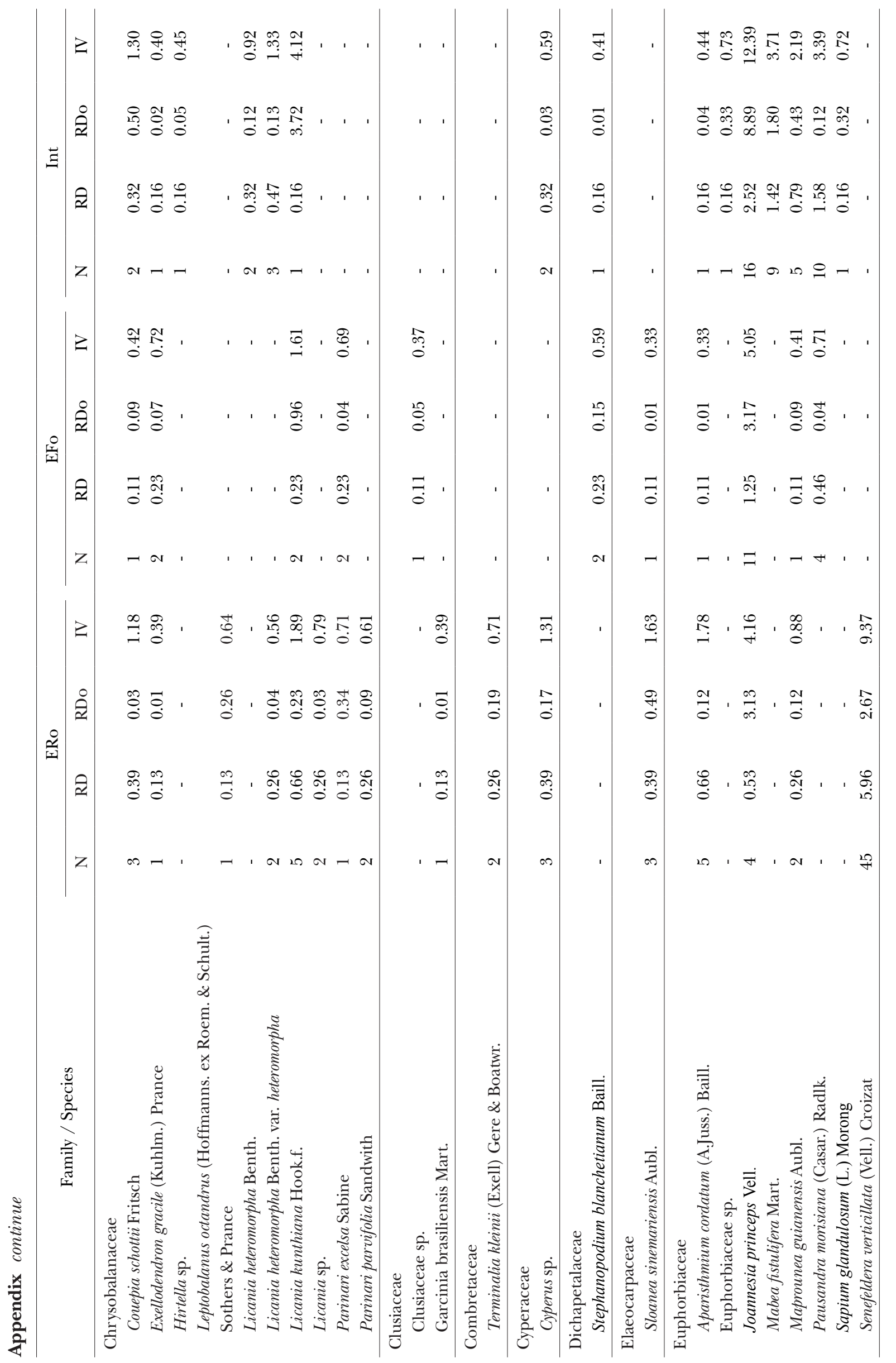




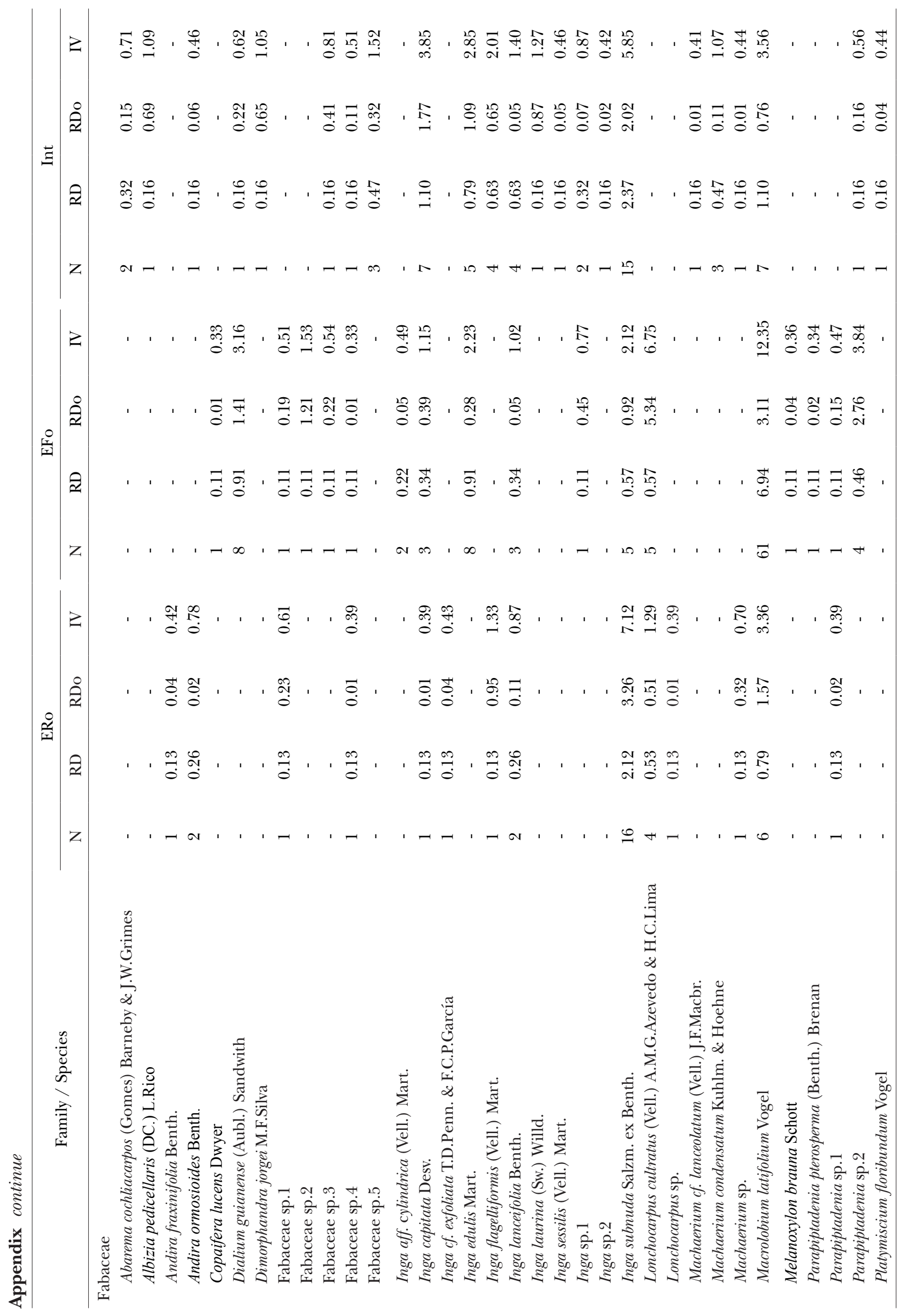




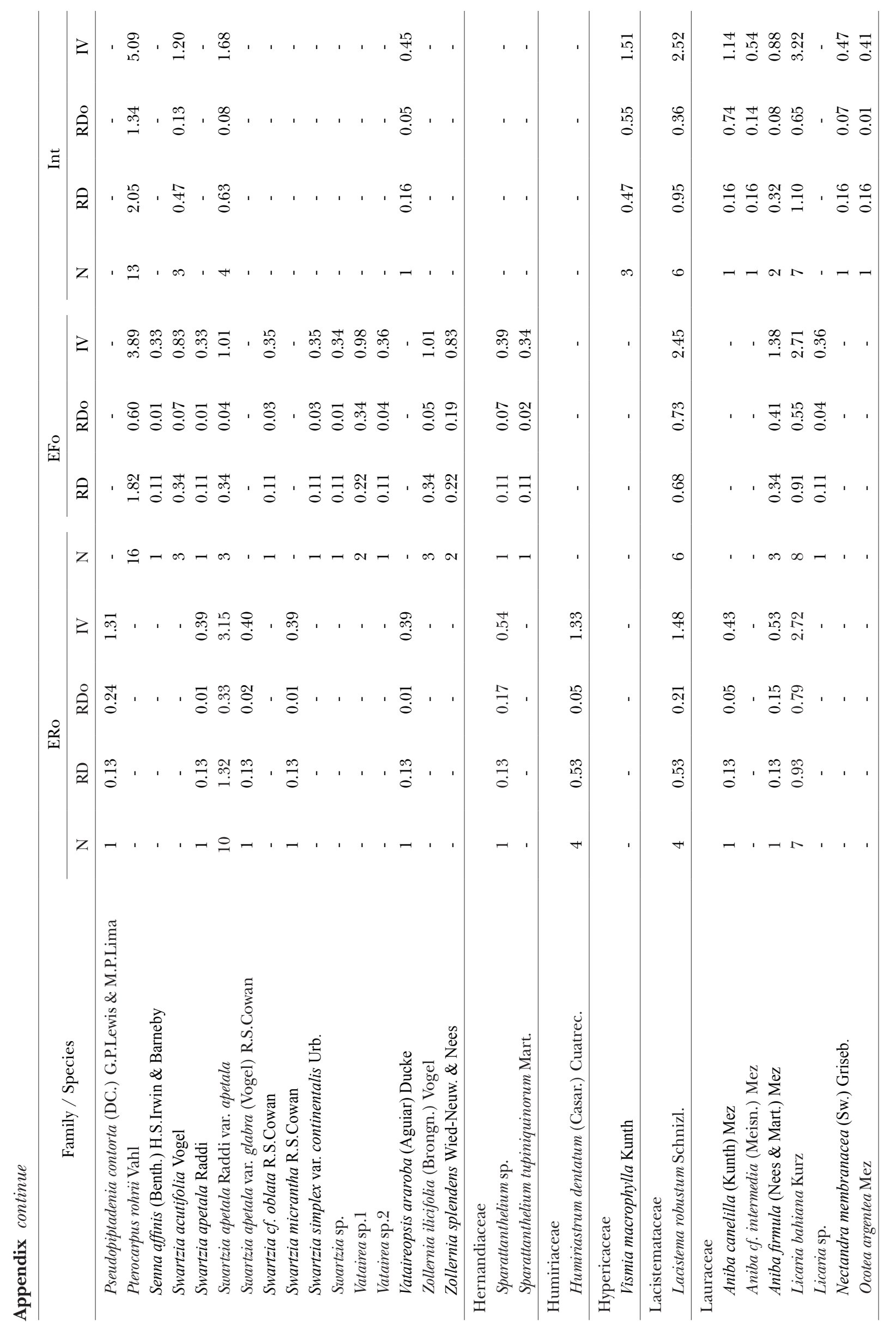




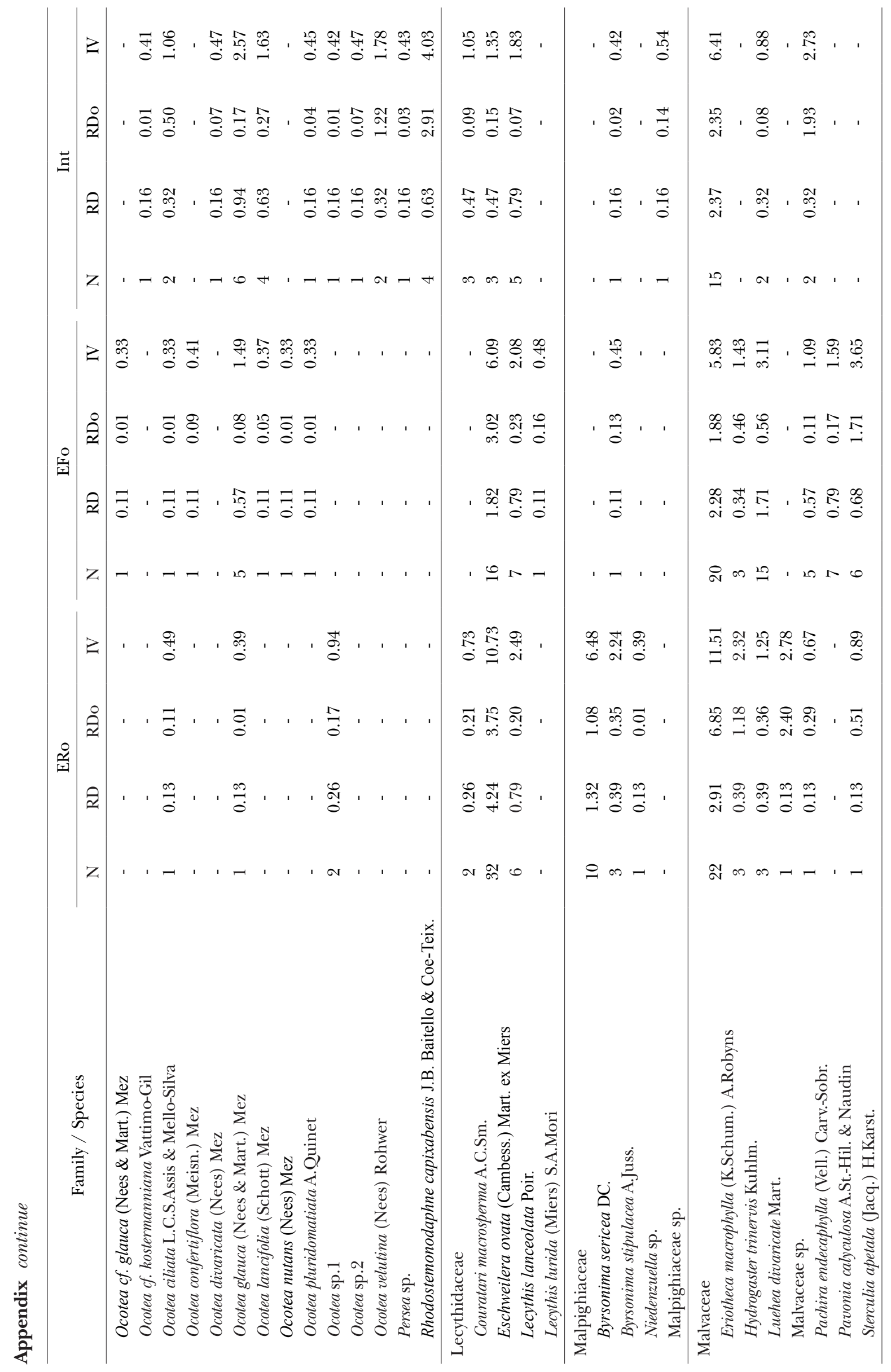




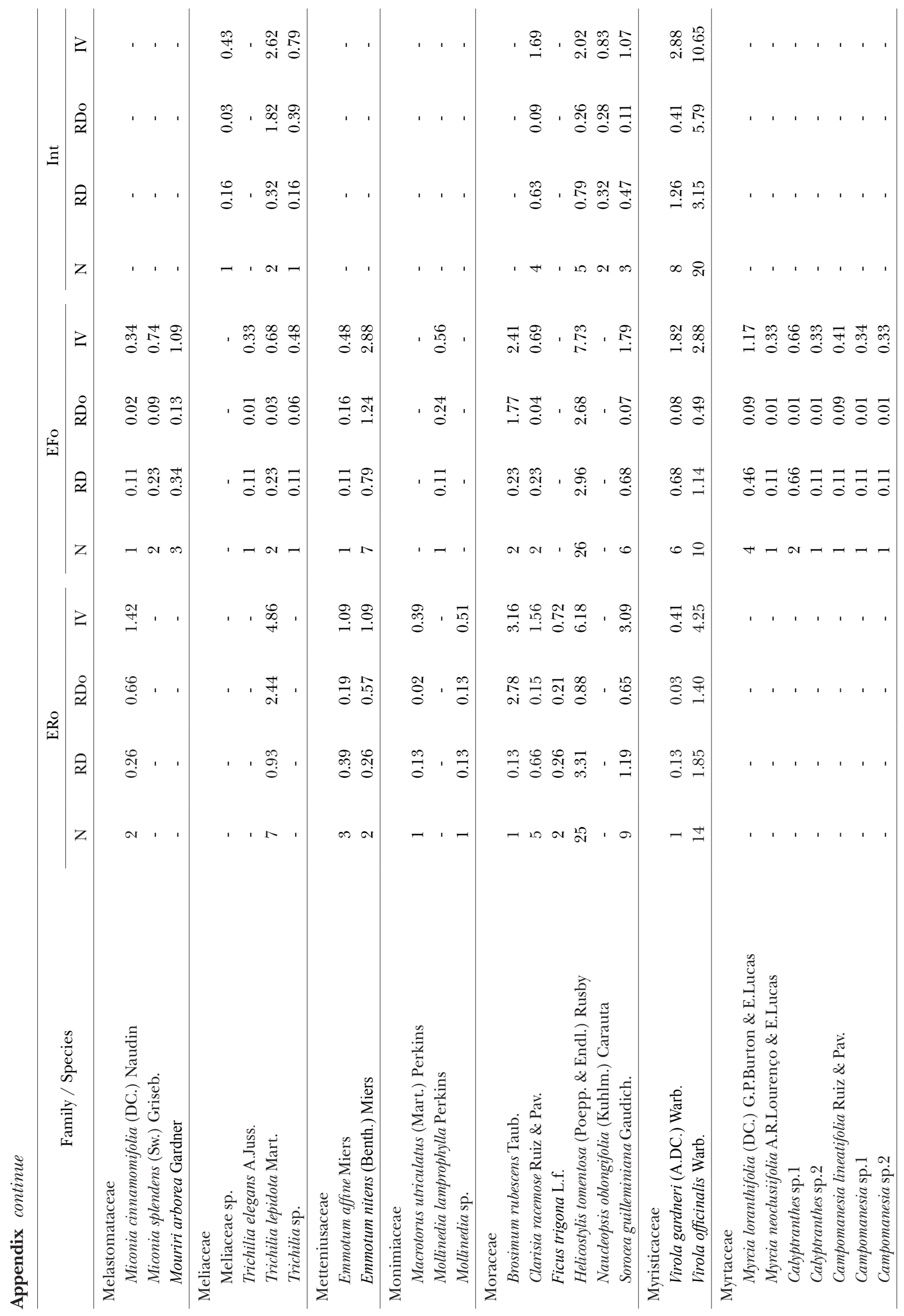




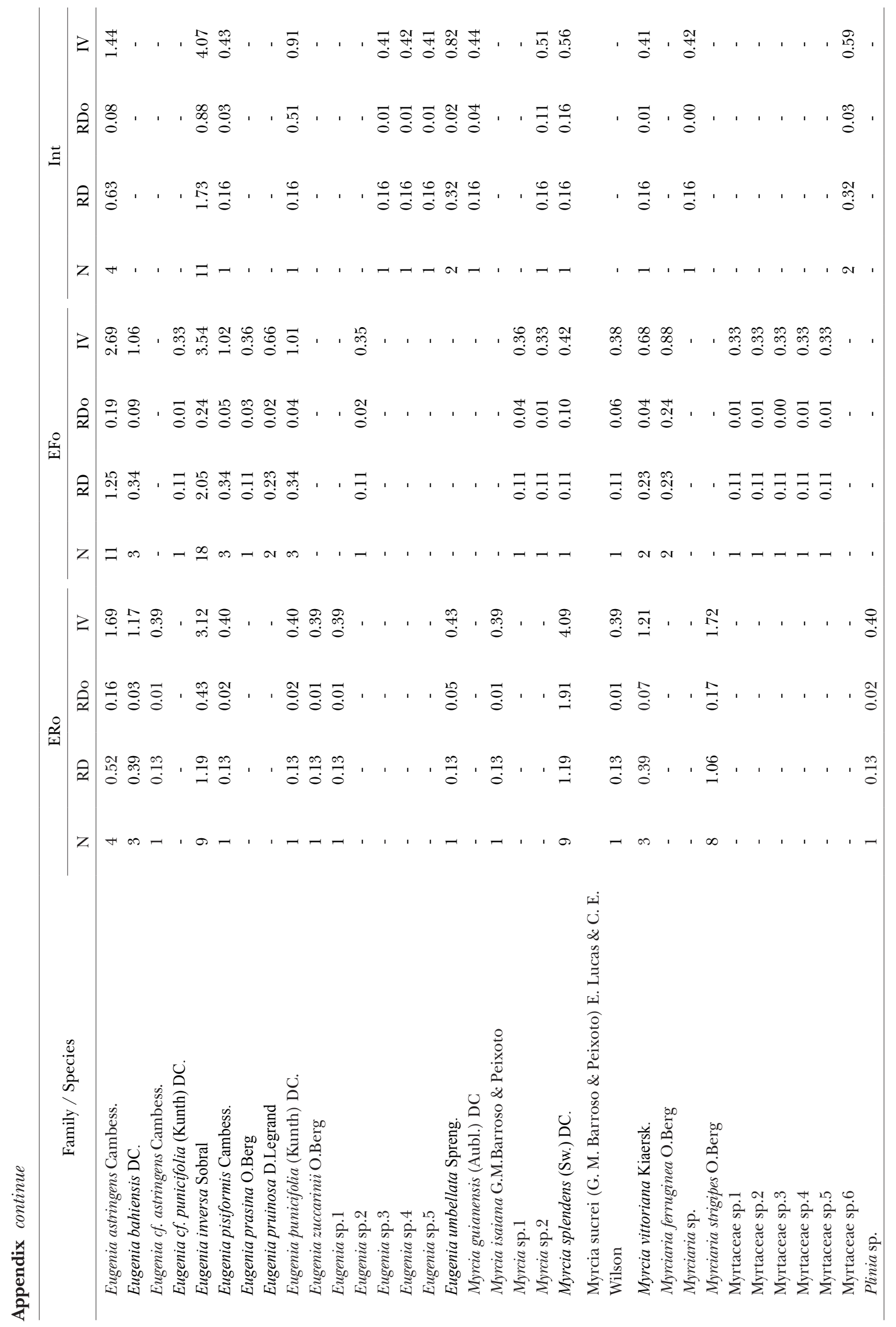




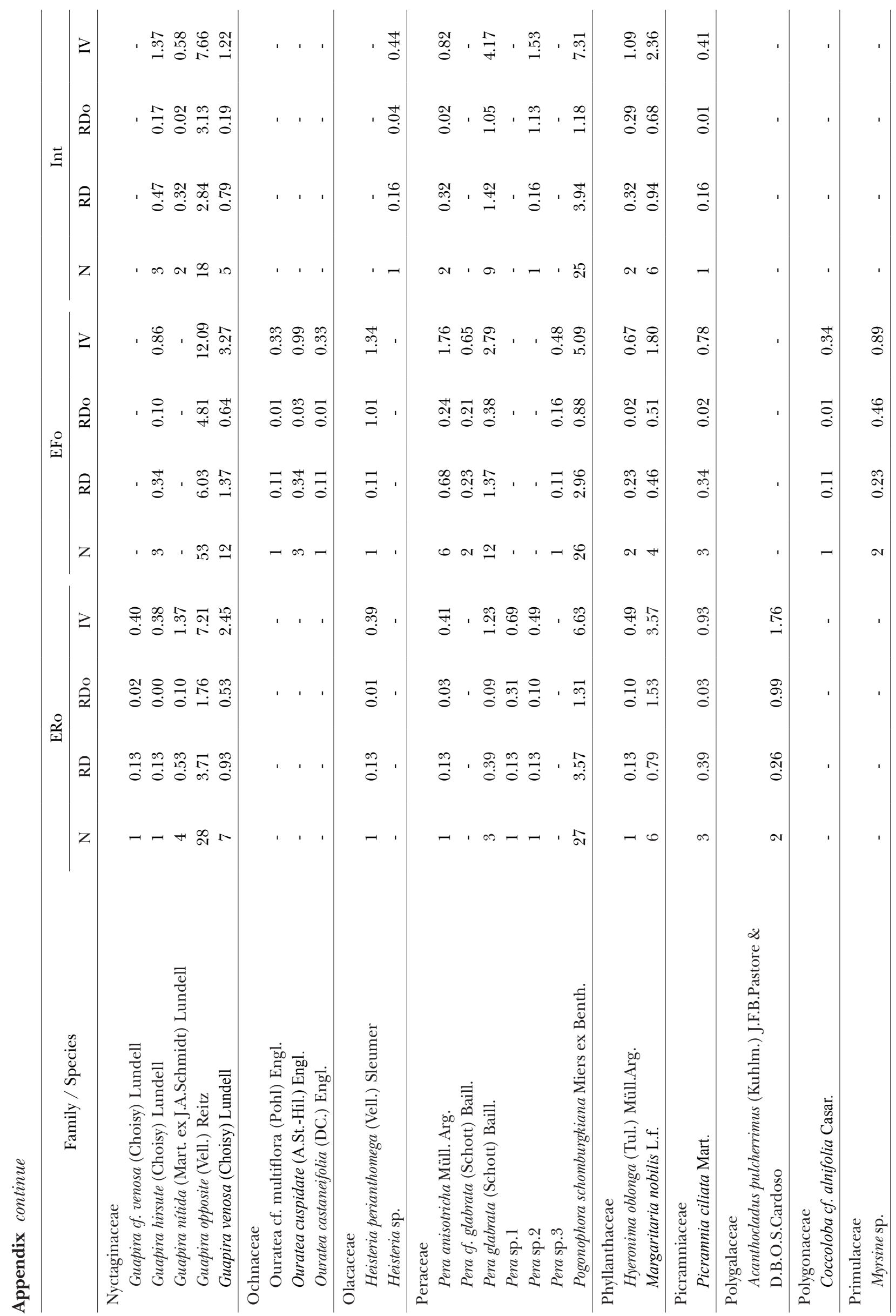




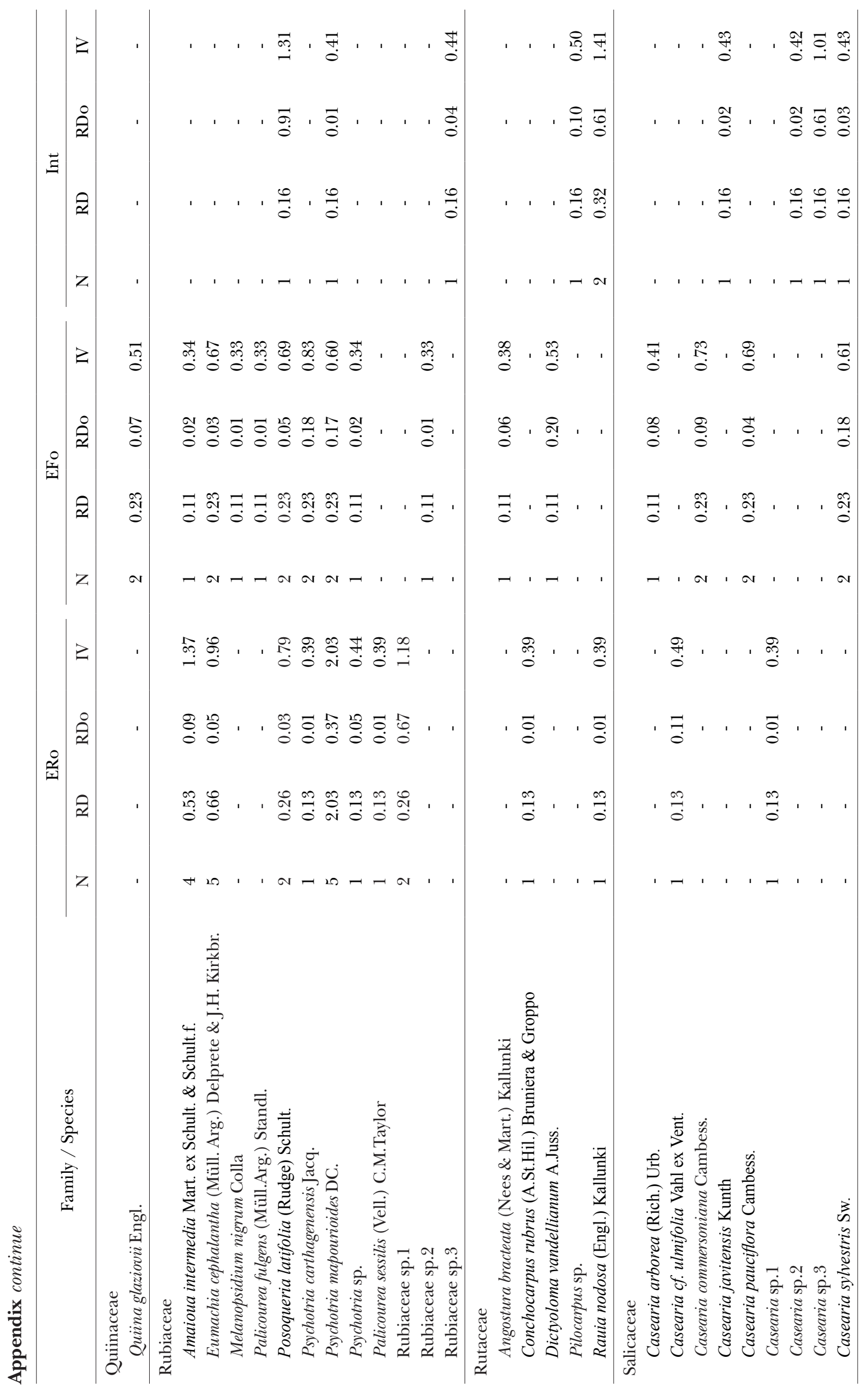




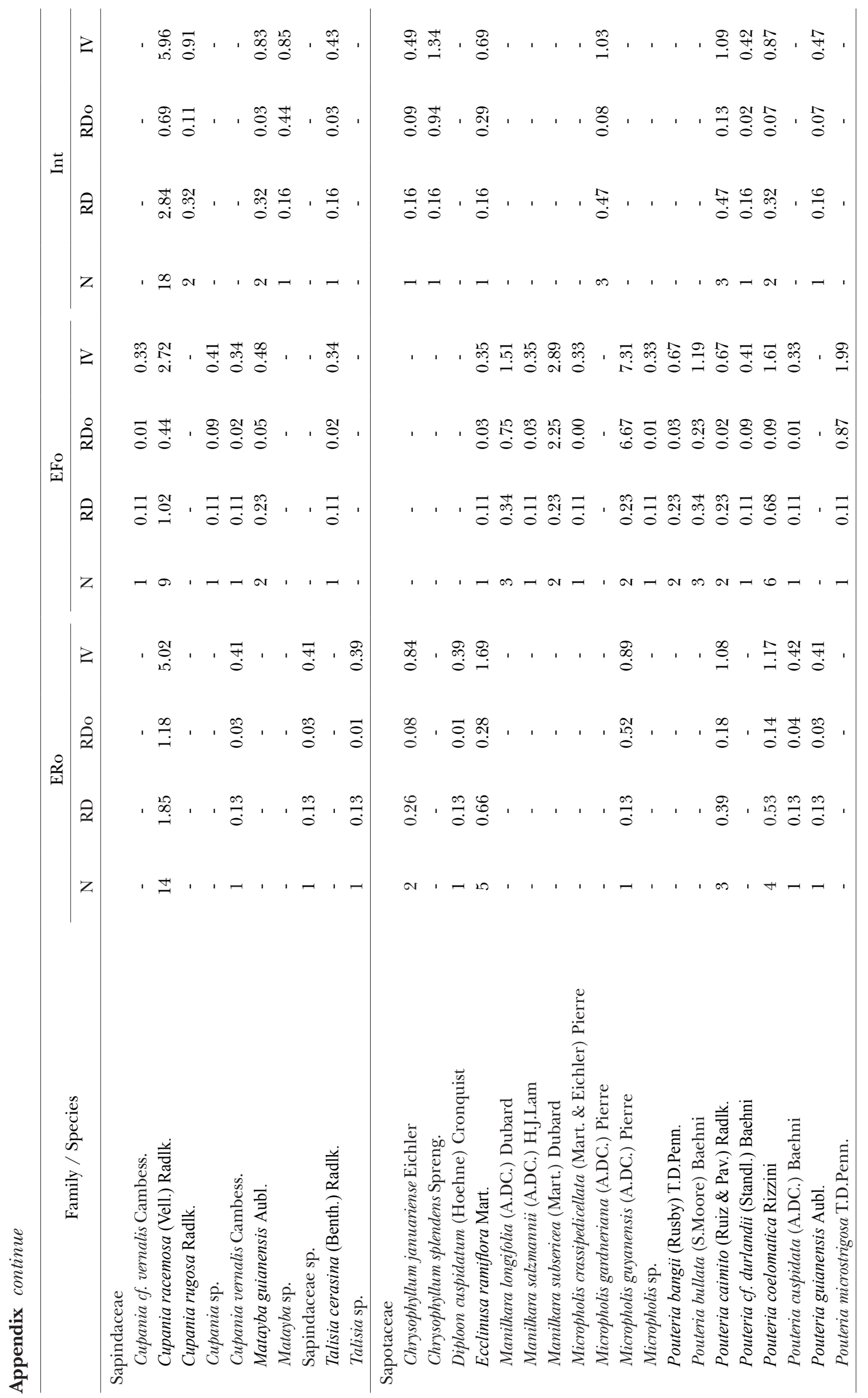




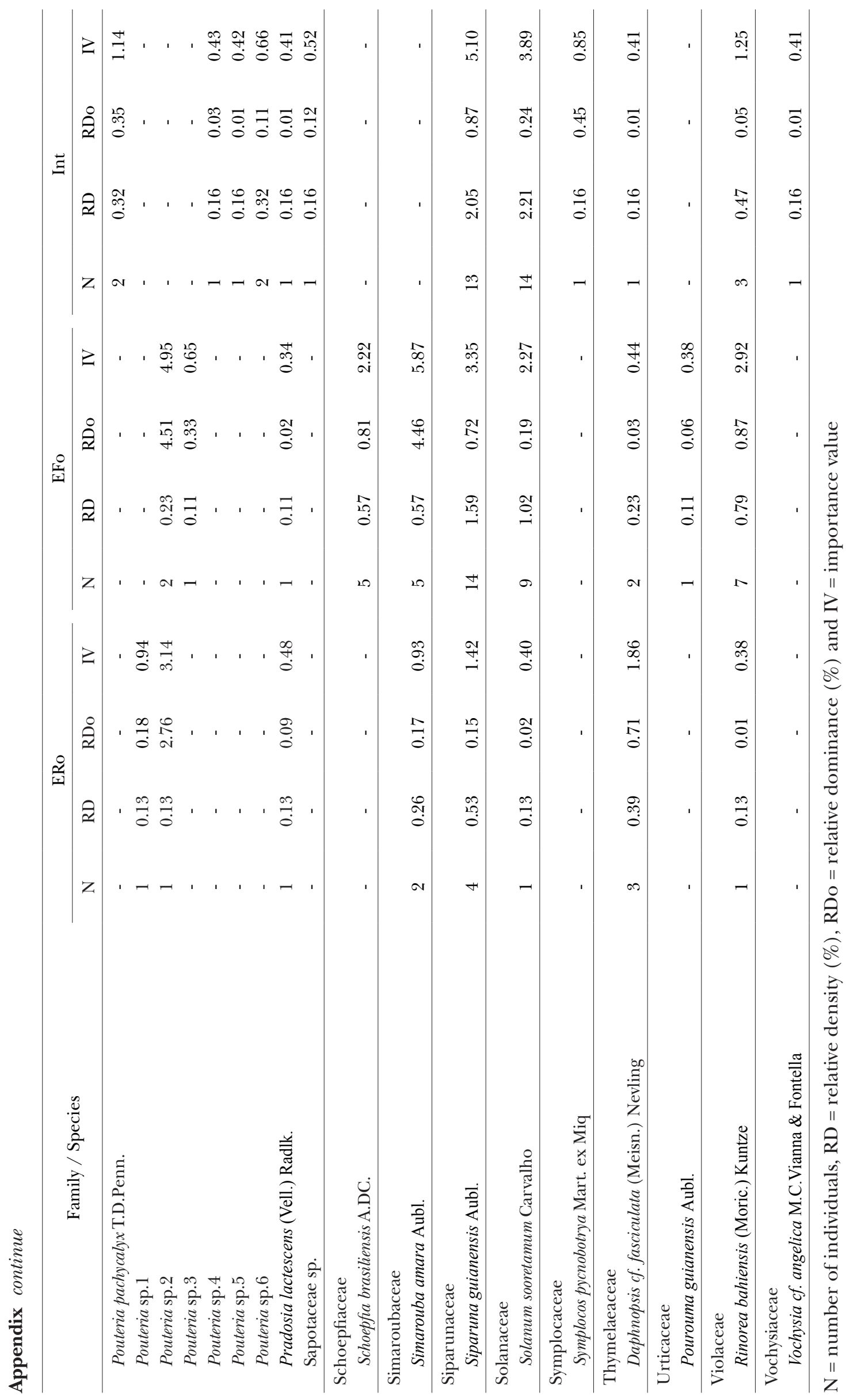

